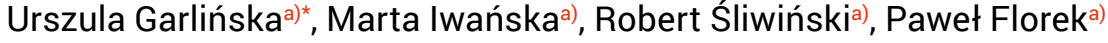 \\ a) Scientific and Research Centre for Fire Protection - National Research Institute / Centrum Naukowo-Badawcze Ochrony \\ Przeciwpożarowej im. Józefa Tuliszkowskiego - Państwowy Instytut Badawczy \\ *Corresponding author / Autor korespondencyjny: ugarlinska@cnbop.pl
}

\title{
The Role of Smoke Detectors and Carbon Monoxide Detectors in the Fire Safety of Residential Buildings
}

\section{Rola czujek dymu i czujek tlenku węgla w bezpieczeństwie pożarowym obiektów mieszkalnych}

\begin{abstract}
Purpose: The aim of this publication is to present the most important aspects of using smoke and carbon monoxide detectors intended for households or similar residential facilities as well as to indicate the advantages and disadvantages of the adopted system solutions that affect the number of detectors installed in this kind of buildings. The article aims to present the issues related to the Integrated Qualifications System (ZSK), i.e. newly developed market qualification, dedicated to installers and maintenance technicians of smoke and carbon monoxide detectors.

Introduction: Smoke and carbon monoxide detectors for early detection of existing threats such as fires or escaping carbon monoxide are an important element of fire protection, dedicated primarily to owners of residential buildings. In many countries in the EU it is obligatory to install detectors in homes, whereas at the moment in Poland the only aspect regulated legally is the obligation of the manufacturer of these products to obtain a certificate. Since 2016, the ZSK has been operating in Poland, in which in 2019 the qualifications of installers/maintenance technicians of smoke and carbon monoxide detectors were distinguished. As a result, a person with a market qualification certificate is prepared for independent installation and maintenance of fire safety monitoring devices

Methodology: As part of the research process, theoretical research was used, such as: analysis of literature and legal documents, synthesis, generalization, inference, comparison and analogy. As part of the research, documents from such countries as Poland, Great Britain (mainly England), Germany and France were analysed. The selection of individual countries was guided by the level of development of these systems in a given country and the availability of source documents

Conclusions: The presented analysis of the requirements for the installation of the smoke and carbon monoxide detectors shows how different the approach is regarding the use of this type of devices. Depending on experiences and the administrative structure of a given country, a variety of regulations, whether legal or normative, can be discerned in the use of smoke and carbon monoxide detectors. ZSK is a well-described system of formal organization and classification of competences and offers the public services at the highest possible quality level. It is also a partial solution to the problem of installing detectors. However, it is necessary to regulate this issue from the legal level, as it was the case in other EU countries, where the installation of detectors in homes is obligatory. Such action will contribute to reducing the victims of fires or inhalation of toxic gases (carbon monoxide)

Keywords: Integrated Qualifications System (ZSK), smoke alarm detector, electrical apparatus for the detection of carbon monoxide, carbon monoxide, residential buildings

Type of article: review article
\end{abstract}

Received: 11.06.2021; Reviewed: 28.06.2021; Accepted: 29.06.2021;

Authors' ORCID IDs: U. Garlińska - 0000-0002-7119-4071; M. Iwańska - 0000-0003-4815-7296; R. Śliwiński - 0000-0002-7309-1332; Pawet Florek - 0000-0002-9690-3989;

The authors contributed the equally to this article;

Please cite as: SFT Vol. 57 Issue 1, 2021, pp. 114-133, https://doi.org/10.12845/sft.57.1.2021.8;

This is an open access article under the CC BY-SA 4.0 license (https://creativecommons.org/licenses/by-sa/4.0/).

\section{ABSTRAKT}

Cel: Celem niniejszej publikacji jest przedstawienie najważniejszych aspektów stosowania czujek dymu i czujek tlenku węgla w prywatnych obiektach mieszkalnych, a także wskazanie zalet oraz wad przyjętych rozwiązań systemowych, które mają wpływ na liczbę detektorów montowanych w tego typu obiektach. Artykuł przedstawia również zagadnienia związane z Zintegrowanym Systemem Kwalifikacji (ZSK), tj. opracowanej kwalifıkacji rynkowej, dedykowanej monterom i konserwatorom czujek dymu i czujek tlenku węgla. 
Wprowadzenie: Czujki dymu i czujki tlenku węgla to ważny element zabezpieczeń obiektów mieszkalnych. Dedykowane są one wszystkim właścicielom tych obiektów. W wielu krajach UE obligatoryjne jest montowanie czujek w domach, natomiast obecnie w Polsce wymagane jest jedynie ich certyfikowanie przez producenta. Od 2016 roku w Polsce funkcjonuje ZSK, w którym w roku 2019 wyodrębniono kwalifikacje dla monterów/konserwatorów czujek dymu i czujek tlenku węgla. Dzięki temu osoba posiadająca certyfikat kwalifikacji rynkowej jest przygotowana do samodzielnego montażu i konserwacji urządzeń monitorujących bezpieczeństwo pożarowe.

Metodologia: W ramach procesu badawczego wykorzystano badania teoretyczne, takie jak: analiza literatury i dokumentów prawnych, synteza, uogólnianie, wnioskowanie, porównanie oraz analogia. Podczas badań dokonano analizy dokumentów z Polski, Wielkiej Brytanii (głównie Anglii), Niemiec i Francji. Przy ich doborze kierowano się poziomem rozwoju tych systemów w danym kraju oraz dostępnością dokumentów źródłowych.

Wnioski: Przedstawiona analiza wymagań w zakresie obowiązku instalacji czujek dymu i czujek tlenku węgla pokazuje, jak różne jest podejście do ich stosowania w Polsce i w wybranych państwach europejskich. W zależności od doświadczeń oraz struktury administracyjnej danego kraju można dostrzec różnorodność przepisów prawnych czy normatywnych. ZSK jest opisanym systemem formalnego uporządkowania i klasyfikacji kompetencji i oferuje społeczeństwu usługi na możliwie najwyższym poziomie jakościowym. Niezbędne jest prawne uregulowanie tej kwestii, tak jak zostało to zrobione w innych krajach UE, gdzie instalacja czujek w domach jest obowiązkowa. Takie działanie przyczyni się do zredukowania ofiar pożarów lub zaczadzeń. Słowa kluczowe: Zintegrowany System Kwalifikacji (ZSK), autonomiczna czujka dymu, autonomiczna czujka tlenku węgla, tlenek węgla (czad), obiekty mieszkalne

Typ artykułu: artykuł przeglądowy

Przyjęty: 11.06.2021; Zrecenzowany: 28.06.2021; Zaakceptowany: 29.06.2021;

Identyfikatory ORCID autorów: U. Garlińska - 0000-0002-7119-4071; M. Iwańska - 0000-0003-4815-7296; R. Śliwiński - 0000-0002-7309-1332; Paweł Florek - 0000-0002-9690-3989;

Autorzy wnieśli równy wkład merytoryczny w powstanie artykułu;

Proszę cytować: SFT Vol. 57 Issue 1, 2021, pp. 114-133, https://doi.org/10.12845/sft.57.1.2021.8;

Artykuł udostępniany na licencji CC BY-SA 4.0 (https://creativecommons.org/licenses/by-sa/4.0/).

\section{Introduction}

Alarm detectors of early detection of common threats, such as fires or escaping carbon monoxide, are a very important, if not the most important, element of fire protection, intended primarily for retail users, i.e. the owners of private residential buildings, i.e. buildings classified in terms of people threat as ZL IV due to fire safety. These alarm detectors, simple in design, very easy to use are of great importance for the safety of people and effective protection of property, especially taking into account such an important aspect for the course of the rescue operation as the moment of alerting about a threat. The chances of preventing the development of an incident on one's own, e.g. by extinguishing a fire or evacuating from the place where the fire started, depends directly on how early people in the danger zone are alerted of the circumstances dangerous to their life or health. The situation is similar with regard to the chances of effective rescue and firefighting activities undertaken by professional services who came to the scene. In this case the effectiveness of the provided assistance also directly depends on the moment of alerting, i.e. identifying the threat. The sooner help is called, the better the chances are for effective protection of life, health and property. Carbon monoxide is an odorless, colorless and deadly poisonous substance which in concentrations exceeding the norms poses a direct threat to human life and health. The operation of alarm detectors has a decisive impact on the survival of people in rooms where carbon monoxide is present. It is similar in the case of gas escaping in the rooms, the ignition and explosion of which is most often the most tragic. Also here the earliest possible detection and alarming are essential, as they decide whether people in the premises or in the adjacent area are able to evacuate safely

\section{Wprowadzenie}

Autonomiczne czujki wczesnej detekcji powszechnie występujących zagrożeń, takich jak pożary czy też ulatniający się tlenek węgla, to bardzo ważny, jeśli nie najważniejszy, element zabezpieczeń przeciwpożarowych, przeznaczony przede wszystkim dla użytkowników detalicznych, tj. właścicieli prywatnych obiektów mieszkalnych, czyli obiektów ze względu na bezpieczeństwo pożarowe zaliczanych do kategorii zagrożenia ludzi ZL IV. Te autonomiczne, nieskomplikowane konstrukcyjnie, bardzo łatwe w obsłudze urządzenia mają ogromne znaczenie dla bezpieczeństwa ludzi oraz skutecznej ochrony mienia, szczególnie biorąc pod uwagę tak istotny dla przebiegu akcji ratowniczej aspekt, jak moment zaalarmowania o zaistniałym zagrożeniu. Szanse samodzielnego zapobiegnięcia rozwojowi zdarzenia, np. poprzez ugaszenie pożaru lub ewakuację z miejsca, w którym doszło do zaprószenia ognia, zależą wprost proporcjonalnie od tego, jak wcześnie osoby przebywające $w$ strefie zagrożenia zostaną zaalarmowane o wystąpieniu okoliczności niebezpiecznych dla ich życia lub zdrowia. Analogicznie sytuacja przedstawia się wobec szans skutecznych działań ratowniczo-gaśniczych podejmowanych przez profesjonalne służby przybyłe na miejsce zdarzenia. Skuteczność udzielanej pomocy również $w$ tym przypadku jest wprost zależna od momentu zaalarmowania, czyli zidentyfikowania zagrożenia. Im wcześniej zostanie wezwana pomoc, tym większe są szanse na skuteczną ochronę życia, zdrowia oraz mienia. Tlenek węgla, potocznie zwany czadem, jest bezwonną, bezbarwną i śmiertelnie trującą substancją, która w stężeniach przekraczających normy stanowi bezpośrednie zagrożenie dla życia i zdrowia ludzi. Decydujący wpływ na przeżycie ludzi znajdujących się w pomieszczeniach, w których obecny jest tlenek węgla, ma właśnie działanie 
on time. A detector guarantees that the alarm is triggered in the first seconds, giving a chance of escape and survival.

Unfortunately, despite universal access, as well as a relatively low cost of purchasing an alarm detector, there is still low public awareness (not only in Poland) of fire threats and a widespread belief that fire is a random accident. As a result, too few households are equipped with these devices, which are of great importance for people's safety and the protection of their property. On one hand, this situation is a consequence of heterogeneous legal regulations, which differ depending on the Member State of the European Union, and, on the other hand, as is the case in Poland, the result of allowing citizens to independently decide whether or not to apply such solutions as detectors in residential buildings.

This article is an overview and its aim is to present, from the perspective of developed European countries, all the most important aspects (functional, operational, legal) of the use of alarm detectors in private residential buildings. The article also presents the advantages of system solutions adopted in selected European countries (including Poland), which affect the level of saturation of the residential infrastructure in these countries in such simple and, at the same time, very important device for safety. autonomicznych czujek. Podobnie jest w sytuacji ulatniającego się w pomieszczeniach gazu, którego zapłon i wybuch najczęściej bywa najtragiczniejszy w skutkach. Tu również bardzo istotna jest możliwie najwcześniejsza detekcja i alarmowanie, które decydują o tym, czy osoby przebywające w pomieszczeniach lub na terenie przyległym, zdołają na czas bezpiecznie się ewakuować. Czujka gwarantuje, że alarm zostanie wszczęty w pierwszych sekundach, dając szansę ucieczki i przeżycia.

Niestety mimo powszechnego dostępu, a także relatywnie niskich kosztów zakupu autonomicznej czujki, wciąż nie tylko w Polsce funkcjonuje niska świadomość społeczna na temat zagrożeń pożarowych oraz powszechne przekonanie o tym, że pożar to przypadłość losowa. W rezultacie zbyt mało gospodarstw domowych jest wyposażonych w te urządzenia, które mają ogromne znaczenie dla bezpieczeństwa ludzi oraz ochrony ich mienia. Sytuacja ta jest z jednej strony konsekwencją niejednorodnych regulacji prawnych, które różnią się między sobą w zależności od państwa członkowskiego Unii Europejskiej, a z drugiej, tak jak ma to miejsce w Polsce, rezultatem pozwolenia obywatelom na samodzielne podjęcie decyzji co do stosowania, bądź nie, takich rozwiązań jak czujki w obiektach mieszkalnych.

Niniejszy artykuł ma charakter przeglądowy, a jego celem jest przedstawienie na podstawie rozwiniętych państw europejskich wszystkich najważniejszych aspektów (funkcjonalnych, użytkowych, prawnych) stosowania autonomicznych czujek w prywatnych obiektach mieszkalnych. Artykuł prezentuje także zalety rozwiązań systemowych przyjętych w wybranych krajach Europy (w tym w Polsce), które wpływają na poziom nasycenia infrastruktury mieszkalnej $w$ tych państwach $w$ tak nieskomplikowane, a jednocześnie tak bardzo istotne dla bezpieczeństwa urządzenia.

\section{Opis działania i funkcjonalności czujek}

\section{Description of the operation and functionality of detectors}

Smoke alarm detectors used in residential buildings constitute a technological solution similar in terms of their intended use as fire detectors commonly installed in public utility buildings, which are a component of fire alarm systems. The detection of threats with the use of smoke alarm detectors is possible due to the phenomenon of scattered light. In the event of a fire threat in a facility equipped with a properly installed smoke detector, smoke particles released as a result of incomplete combustion process enter the detection chamber and activate the alarm by refracting the light emitted by the diode. The alarm is carried out by the emission of a modulated audio signal after the detector goes from the quiescent state to the alarm state. The phenomenon of alarm activation in a smoke detector based on the phenomenon of light refraction in the detection chamber is presented in Figure 1 in a simplified manner.
Autonomiczne czujki dymu stosowane w obiektach mieszkalnych stanowią podobne pod względem przeznaczenia rozwiązanie technologiczne jak czujki pożarowe powszechnie instalowane w obiektach użyteczności publicznej będące elementem składowym systemów sygnalizacji pożarowej. Detekcja zagrożeń przy wykorzystaniu autonomicznych czujek dymu jest możliwa dzięki wykorzystaniu zjawiska światła rozproszonego. W sytuacji zagrożenia pożarem w obiekcie wyposażonym w zainstalowaną prawidłowo czujkę dymu wydzielające się w wyniku niecałkowitego procesu spalania cząsteczki dymu dostają się do komory detekcyjnej i aktywują alarm poprzez załamanie światła emitowanego przez diodę. Alarmowanie odbywa się za pomocą emisji modulowanego sygnału akustycznego po przejściu detektora ze stanu dozorowania do stanu alarmowania. Zjawisko aktywacji alarmu w czujce dymu w oparciu o zjawisko załamania światła w komorze detekcyjnej przedstawiono w sposób uproszczony na rycinie 1 . 


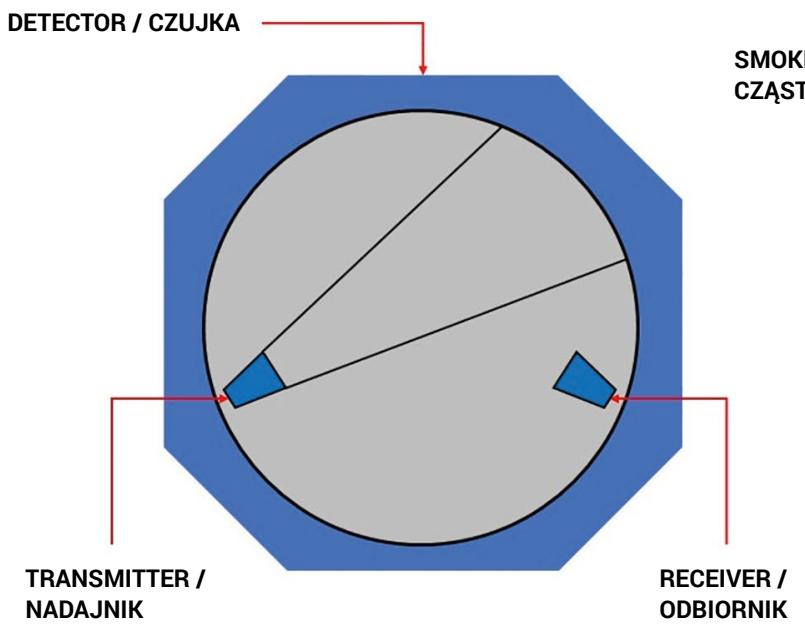

SMOKE PARTICLE / CZĄSTECZKA DYMU

Figure 1. Simplified principle of the operation of a smoke detector

Rycina 1. Uproszczona zasada działania czujki dymu

Source: Own elaboration

Źródło: Opracowanie własne.

The sound intensity values have been strictly defined in order to maintain the basic alarm functionality by the detector by means of a modulated audio signal. The required output value for the levels of emitted sounds, which was specified in PN-EN 14604:2006 [1], should be at least $85 \mathrm{dBA}$ at a distance of 3 meters. After 4 minutes from the detector entering the alarm state, the intensity value of the emitted audio signal at a distance of three meters from the detector should not be less than $82 \mathrm{dBA}$. In buildings where fire alarm systems with sounders have been installed, the minimum values of the intensity of audio signals are $65 \mathrm{dBA}$ at a distance of 1 meter (PN-EN 54-3+A1:2019-06) [2]. Following the requirements of PKN-CEN/ TS 54-14:2020-09 [3] in facilities where a fire alarm system has been installed, it is necessary to ensure uniformity of sound coverage from sounders at a level of not less than $65 \mathrm{dBA}$ at the reception site and at least $75 \mathrm{dBA}$ in places designated for sleeping. Smoke detectors recommended for use in residential buildings have higher certification criteria for the minimum sound level, but there are no installation requirements for them indicating the minimum sound level required at the place of receiving the sound signal. Apart from audio alarming, the manufacturers of detectors offer the functions of various audio messages (depending on the manufacturer and model of the detector), which are designed to inform the user about the battery charge status of the detector and the correct or incorrect technical condition of the detector. These functionalities are important for the correct operation and maintenance of the devices, which affects the useful life and reliability of the detectors. From the perspective of detector usability, a very important element is the detector power supply, which is usually an internally built-in, replaceable battery. All models of the certified detectors are also equipped with battery voltage control systems. The internal power supply of a smoke alarm detector should guarantee proper operation of the detector for a minimum of a year without the need to replace the battery, and should alert users to
Wartości natężenia dźwięków zostały ściśle określone w celu zachowania podstawowej funkcjonalności alarmowania przez czujkę za pomocą modulowanego sygnału akustycznego. Wymagana wartość wyjściowa dla poziomów emitowanych dźwięków, która została określona w normie PN-EN 14604:2006 [1], powinna wynosić minimum $85 \mathrm{dBA}$ w odległości 3 metrów. Po 4 minutach od przejścia czujki w stan alarmowania wartość natężenia emitowanego sygnału akustycznego w odległości trzech metrów od czujki nie powinna być mniejsza niż $82 \mathrm{dBA}$. W obiektach budowalnych, w których zainstalowano systemy sygnalizacji pożarowej z sygnalizatorami akustycznymi, określone wartości minimalne natężenia sygnałów akustycznych wynoszą $65 \mathrm{dBA}$ w odległości 1 metra (PN-EN 54-3+A1:2019-06) [2]. Kierując się wymaganiami PKN-CEN/TS 54-14:2020-09 [3] w obiektach, w których zainstalowano system sygnalizacji pożarowej, należy zapewnić równomierność pokrycia dźwiękiem pochodzącym z sygnalizatorów akustycznych na poziomie nie mniejszym niż $65 \mathrm{dBA}$ w miejscu odbioru oraz co najmniej 75 dBA w miejscach przewidzianych do spania. Czujki dymu rekomendowane do zastosowania w obiektach mieszkalnych mają wyznaczone wyższe kryteria certyfikacyjne dla minimalnego poziomu dźwięku, natomiast nie określono w stosunku do nich wymagań instalacyjnych wskazujących minimalny poziom dźwięku wymagany w miejscu odbioru sygnału dźwiękowego. Producenci czujek oferują poza alarmowaniem akustycznym również funkcje różnych komunikatów dźwiękowych (w zależności od producenta i modelu czujki) mających za zadanie informowanie użytkownika o stanie naładowania baterii zasilających detektor oraz prawidłowym lub nieprawidłowym stanie technicznym czujki. Funkcjonalności te są istotne dla prawidłowej eksploatacji i konserwacji urządzeń, co wpływa na okres przydatności i niezawodności czujek. Bardzo istotnym elementem z perspektywy użyteczności czujek jest źródło zasilania detektorów, którym najczęściej jest wewnętrznie wbudowana, wymienialna bateria. Wszystkie modele certyfikowanych czujek zostały również wyposażone w systemy kontrolujące napięcie baterii. Wewnętrzne źródło zasilania autonomicznej czujki 
the need to replace the battery for at least thirty days before it is fully discharged. At the time of signaling a fault (low battery), the detector must be able to emit an alarm signal for at least four minutes. A very important issue for the proper operation and maintenance of the detector is the users complying with the recommendations of the manufacturer, who in the enclosed technical and operational documentation of the device specifies the recommended battery types, the recommended frequency of their replacement, and how to replace the batteries in a trouble-free manner. Complying with the manufacturer's recommendations guarantees reliable operation of the detector for the period specified in the manual. Depending on the model, there are detectors on the market that, with proper use and maintenance, can last up to ten years. The currently offered detector models, apart from the brand and certification, also differ in terms of additional functionalities. With reference to the harmonized standard EN 14604, which applies to this product group, detector manufacturers may also offer additional detector functionalities. The catalog of additional functions (not regulated and not required by EN 14604) is very wide and allows users to choose a detector model that will take into account various specific characteristics of users or objects. Examples of types of additional functions:

- enabling the connection of many detectors in a network (useful in case of buildings with a large surveillance area),

- providing notification of alarm activation via SMS (useful especially in case of the protection of dependent persons; option used their guardians, temporarily outside the supervised facility),

- self-testing of the detector (important from the point of view of proper operation, maintenance and, consequently, the service life of a properly functioning detector),

- additional emergency lighting (useful especially in a situation of supervising facilities in which there are people with hearing impairments, for whom alarming with only an audio signal may prove insufficient),

- integrated indicator of detector activation by means of additional diode indications (light signaling informing not only about the detector's power supply status, but also separately about the detector switching from the quiescent state to the alarm state),

- remote transmission enabling connection of other detectors installed in the protected facility to the network by means of dedicated software.

In the context of the last of the additional functions mentioned above, it is worth mentioning that some of the certified products have the ability to connect, for example, to a mobile phone equipped with appropriate software and verify the detector status from this level, as well as to reset the alarm state from a mobile phone or other remote device. However, the requirement set out by EN 14604:2005, requires the user to appear at the detector installation site and to verify whether it is a dangerous state or a false alarm, resulting e.g. from too close installation of the detector in relation to a potential heat source, e.g. household appliances. On the other hand, it is dymu powinno gwarantować zachowanie prawidłowego działania czujki przez minimum rok bez konieczności wymiany baterii, a także alarmować użytkowników o konieczności wymiany akumulatora przez co najmniej trzydzieści dni przed całkowitym rozładowaniem. W momencie sygnalizacji uszkodzenia (rozładowania baterii) wymagana jest zdolność czujki do emisji sygnału alarmu przez co najmniej cztery minuty. Bardzo istotną sprawą dla prawidłowej eksploatacji i konserwacji czujki jest stosowanie się przez użytkowników do zaleceń producenta, który w załączonej dokumentacji techniczno-użytkowej urządzenia określa rekomendowane typy akumulatorów, zalecaną częstotliwość ich wymiany, a także jak w bezawaryjny sposób należy przeprowadzać wymianę baterii. Stosowanie się do zaleceń producenta gwarantuje niezawodne działanie czujki przez okres wskazany w instrukcji. W zależności od modelu na rynku dostępne są czujki, których okres przydatności może wynosić przy właściwym użytkowaniu i konserwacji nawet dziesięć lat. Oferowane obecnie modele detektorów, poza marką i posiadaną certyfikacją, różnią się również dodatkowymi funkcjonalnościami. W odniesieniu do normy zharmonizowanej EN 14604, która dotyczy tej grupy wyrobów, producenci czujek mogą oferować również dodatkowe funkcjonalności czujek. Katalog dodatkowych funkcji (nieuregulowanych i niewymaganych w normie EN 14604) jest bardzo szeroki i pozwala użytkownikom na wybór takiego modelu detektora, który będzie uwzględniał różne specyficzne cechy użytkowników lub obiektów. Przykładowe rodzaje dodatkowych funkcji:

- umożliwiająca połączenie w sieci wielu detektorów (przydatna w przypadku obiektów charakteryzujących się znaczną powierzchnią dozorowania),

- powiadamiania o aktywacji alarmu za pomocą wiadomości SMS (przydatna szczególnie w przypadku ochrony osób niesamodzielnych, z której korzystają ich opiekunowie, przebywający chwilowo poza dozorowanym obiektem),

- samoczynnego testowania detektora (istotna z punktu widzenia właściwej eksploatacji, konserwacji, a w rezultacie okresu użytkowania prawidłowo działającej czujki),

- dodatkowego oświetlenia awaryjnego (przydatna szczególnie w sytuacji dozorowania obiektów, w których przebywają osoby posiadające dysfunkcję słuchu, dla których alarmowanie wyłącznie za pomocą sygnału akustycznego może okazać się niewystarczające),

- zintegrowanego wskaźnika zadziałania detektora za pomocą wskazań dodatkowej diody (sygnalizacja świetlna informująca nie tylko o stanie zasilania detektora, ale oddzielnie również o przejściu czujki ze stanu dozorowania w stan alarmowania),

- zdalnej transmisji umożliwiającej przyłączenie za pomocą dedykowanego oprogramowania do sieci innych detektorów zainstalowanych w chronionym obiekcie.

W kontekście ostatniej z wymienianych powyżej dodatkowych funkcji warto nadmienić, że część certyfikowanych wyrobów posiada możliwość połączenia, np. z telefonem komórkowym wyposażonym w odpowiednie oprogramowanie i weryfikację stanu czujki z tego poziomu, jak również umożliwia kasowanie stanu alarmu z poziomu telefonu komórkowego lub innego urządzenia zdalnego. Wymaganie postawione przez normę EN 14604:2005 wymusza jednak pojawienie się użytkownika w miejscu zainstalowania czujki 
not recommended to use external applications to reset alarm states from smoke detectors.

The location of the detector, i.e. the place of its installation, affects both the level of security guaranteed by a properly operating device and the risk of possible false alarms. When deciding to install a smoke detector, it is recommended to locate it in passageways, staircases, corridors or passages. In case of multi-storey buildings, it is worth ensuring that a detector or detectors are installed on each storey, depending on the area. As for the other rooms recommended for the location of detectors, they certainly include bedrooms and rooms where dependent people are staying (children, bedridden people or the elderly). Each detector model has its own performance characteristics, which include the optimal location of the device specified by the manufacturer. It is usually recommended that the detector be installed on ceilings at a distance of not less than $10-20 \mathrm{~cm}$ from walls, and also away from ventilation, air conditioning and appliances such as stoves or lighting lamps, which may emit gases when heated significantly. It is also recommended to avoid locating the detectors in areas where there may be significant dust or water vapor. Due to practical reasons, the detectors should not be installed in hard-to-reach places. This may have a negative impact on the operation and maintenance conditions of the detector, including periodic tests of its efficiency, which should be carried out manually with a frequency of not less than once a month. In the event of repeated, unjustified alarms, it is recommended to revise the original location of the detector and, if necessary, change it. In the event of persistent false alarms, the user should contact the point of sale or the authorized service center directly as quickly as possible.

Figures 2 and 3 show possible variants of protection levels depending on the number of sensors installed, i.e. minimum and optimal protection.

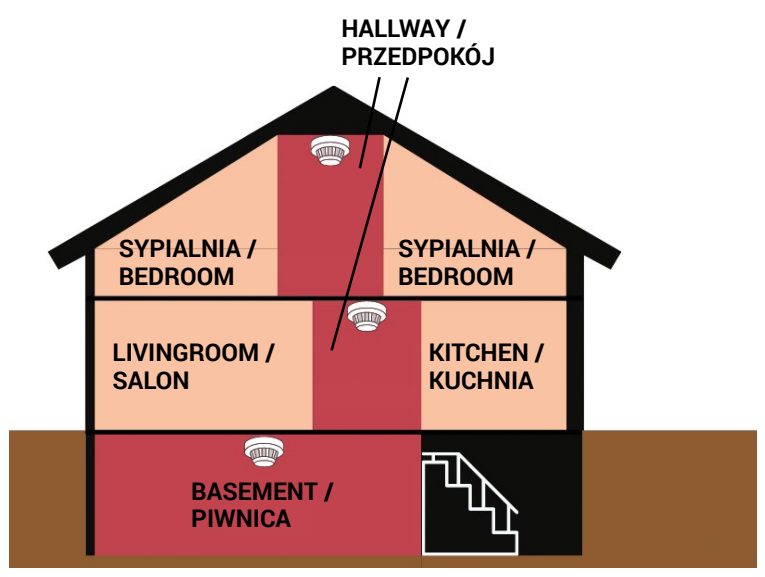

Figure 2. Arrangement of the smoke detector - minimal protection Rycina 2. Rozmieszczenie czujki dymu - ochrona minimalna

Source: Own elaboration.

Źródło: Opracowanie własne. i weryfikację, czy mamy do czynienia ze stanem niebezpiecznym, czy może jest to alarm fałszywy wynikający np. ze zbyt bliskiego zainstalowania czujki w stosunku do potencjalnego źródła ciepła np. urządzeń AGD. Nie zaleca się jednak wykorzystywania zewnętrznych aplikacji do kasowania stanów alarmowych z czujek dymu.

Lokalizacja czujki, czyli miejsce jej zainstalowania, ma wpływ zarówno na poziom bezpieczeństwa gwarantowany przez prawidłowo działające urządzenie, jak i na ryzyko ewentualnych fałszywych alarmów. Podejmując decyzję o instalacji czujki dymu, zaleca się jej lokalizację w ciągach komunikacyjnych, na klatkach schodowych, w korytarzach lub przejściach. W przypadku obiektów wielokondygnacyjnych warto zadbać o to, aby na każdej kondygnacji była zainstalowana czujka lub czujki w zależności od powierzchni. Jeśli chodzi o pozostałe pomieszczenia zalecane do lokalizacji czujek z pewnością należą do nich sypialnie oraz pomieszczenia, w których przebywają osoby niesamodzielne (dzieci, osoby obłożnie chore czy też osoby w podeszłym wieku). Każdy model czujki posiada swoje właściwości użytkowe, do których należy określona przez producenta optymalna lokalizacja urządzenia. Zazwyczaj zaleca się, aby detektor był instalowany na stropach w odległości nie mniejszej niż 10-20 cm od ścian, a także z dala od urządzeń wentylacyjnych, klimatyzacyjnych oraz urządzeń typu kuchenki lub lampy oświetleniowe, które mogą emitować gazy w wyniku znacznego nagrzania. Zaleca się także, aby unikać lokalizacji detektorów w miejscach, w których może występować znaczne zapylenie lub para wodna. Z powodów praktycznych nie należy montować detektorów w miejscach trudno dostępnych. Może to bowiem mieć niekorzystny wpływ na warunki eksploatacji i konserwacji czujki, w tym okresowe testy jej sprawności, które powinno się przeprowadzać ręcznie z częstotliwością nie mniejszą niż raz na miesiąc. W sytuacji powtarzających się dosyć często nieuzasadnionych alarmów zaleca się rewizję pierwotnej lokalizacji czujki i jej ewentualną zmianę. W przypadku nieustania fałszywych alarmów, należy w miarę szybko skontaktować się z punktem sprzedaży lub bezpośrednio $z$ autoryzowanym punktem serwisowym.

Na rycinie 2 i 3 zostały przestawione możliwe warianty poziomów ochrony w zależności od liczby zainstalowanych czujników, tj. minimalnej i optymalnej ochrony.

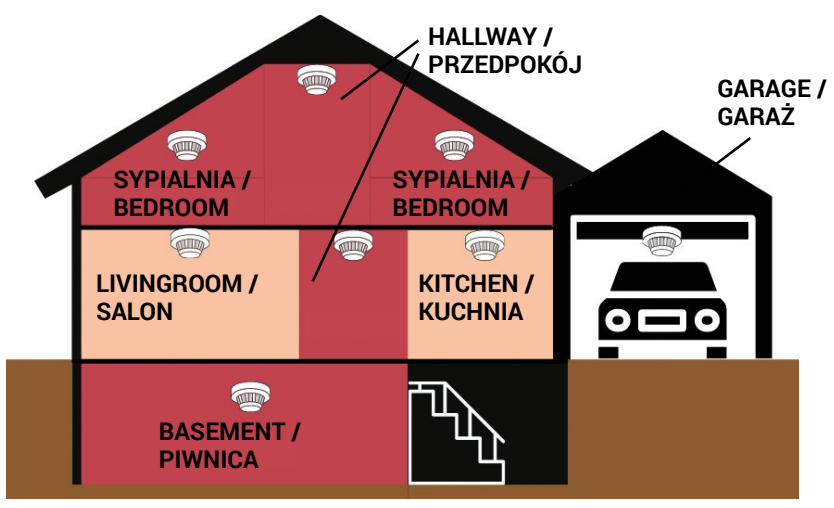

Figure 3. Arrangement of the smoke detector - optimal protection Rycina 3. Rozmieszczenie czujki dymu - ochrona optymalna

Source: Own elaboration.

Źródło: Opracowanie własne. 
Particular attention should be paid to installing a smoke detector in rooms located in basements, where most often heating sources are also installed (e.g. in single-family houses). In such cases, apart from installing a smoke detector, it is reasonable to install an additional carbon monoxide detector. Figure 4 shows the optimal location of the detectors in an example onestory house.
Należy zwrócić szczególną uwagę na instalację czujki dymu w pomieszczeniach ulokowanych w piwnicach i podpiwniczeniach, gdzie najczęściej instaluje się również źródła ogrzewania (np. w domach jednorodzinnych). W takich przypadkach, poza instalacją czujki dymu, uzasadniony jest montaż dodatkowego detektora tlenku węgla. Na rycinie 4 przedstawiono optymalną lokalizację czujek w przykładowym jednokondygnacyjnym gospodarstwie domowym.

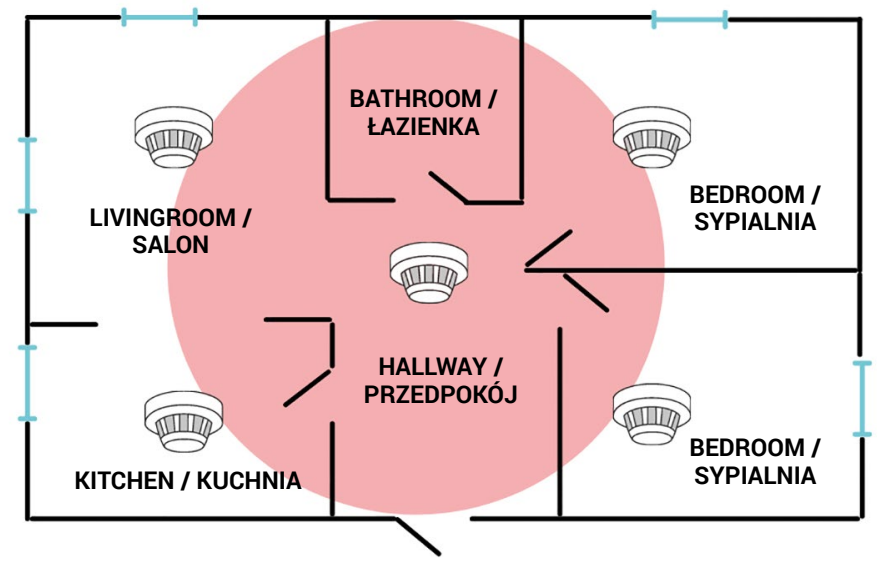

Figure 4. Preferred placement of smoke detectors Rycina 4. Preferowane rozmieszczenie czujek dymu

Source: Own elaboration.

Źródło: Opracowanie własne.

Carbon monoxide detector is another type of detector that is designed to detect the presence of an odorless and colorless, highly poisonous substance, which is carbon monoxide. The design of the carbon monoxide detector is also similar to the detectors commonly used as elements of fire alarm systems. Depending on the model and brand, the measurement of the concentration of carbon monoxide can be carried out using a biometric sensor, in which a special gel is placed that changes color depending on the specified amount of carbon monoxide. Currently, the market offer includes semiconductor or electrochemical detectors.

As in the case of smoke detectors, carbon monoxide detectors must be equipped with an audio signaling device that will signal at a level of at least $85 \mathrm{dBA}$ (measured at a distance of 3 meters) after 1 minute from activation and at a level of $82 \mathrm{dBA}$ after 4 minutes of alarming (PN-EN 50291-1:2018) the exceeding amount of a given carbon monoxide threshold [4]. Another signaling element, which is the function of the carbon monoxide detector, is optical signaling, which informs the user that the detector is properly powered by means of a diode emitting a green light. By means of a red diode, the detector should communicate the detector's transition from the quiescent state to the alarm state. For detectors powered by an internally built-in battery, a function is required to alert the user of a low battery level. This function is to allow the user to replace the battery at a critical moment, ensuring continuity of protection and proper
Autonomiczna czujka tlenku węgla stanowi kolejny rodzaj detektora, który jest przeznaczony do wykrywania obecności bezwonnej i bezbarwnej, silnie trującej substancji, jaką jest tlenek węgla, potocznie zwany czadem. Autonomiczna czujka tlenku węgla w swojej konstrukcji również jest zbliżona do czujek powszechnie wykorzystywanych jako elementy systemów sygnalizacji pożarowej. W zależności od modelu oraz marki pomiar stężenia tlenku węgla może być realizowany za pomocą sensora biometrycznego, w którym umieszczony jest specjalny żel zmieniający kolor w zależności od określonej ilość tlenku węgla. Obecnie na rynku dostępne są czujki półprzewodnikowe lub elektrochemiczne. Podobnie jak w przypadku autonomicznych czujek dymu, czujki tlenku węgla muszą być wyposażone w sygnalizator akustyczny, który zasygnalizuje przekroczenie danego progu tlenku węgla na poziomie co najmniej $85 \mathrm{dBA}$ (mierzone w odległości 3 metrów) po 1 minucie od zadziałania i na poziomie $82 \mathrm{dBA}$ po 4 minutach alarmowania (PN-EN 50291-1:2018) [4]. Kolejny element sygnalizacji, który stanowi funkcję czujki tlenku węgla to sygnalizacja optyczna, która ma za zadanie informowanie użytkownika o prawidłowym zasilaniu detektora za pomocą diody emitującej światło koloru zielonego. Za pomocą diody o barwie czerwonej detektor powinien komunikować o przejściu detektora ze stanu dozorowania w stan alarmowania. W przypadku czujek zasilanych za pomocą wewnętrznie wbudowanej baterii wymaga się funkcji umożliwiającej alarmowanie użytkownika o niskim poziomie naładowania baterii. Funkcja ta ma pozwolić użytkownikowi 
operation of the detector. Similarly to the recommendations regarding smoke detectors, the batteries in the carbon monoxide detectors should be replaced each time in accordance with the manufacturer's instructions. The models of carbon monoxide detectors currently offered on the market are equipped with liquid crystal panels, due to which the user of the device can monitor the concentration of the carbon monoxide (CO) on an ongoing basis. The models equipped with the panel also allow reading of the $\mathrm{CO}$ concentration during the last alarm activation. This is possible due to the internal memory. Due to the function of archiving measurements, the user can control the operation of the device when not in the facility where the sensor is installed. As a result, even in such a situation, each activated alarm will be noticed, which is important for the user, as well as confirms the legitimacy of monitoring the room for life-threatening and health-threatening $\mathrm{CO}$ concentrations in this facility or a specific room.

The most technologically advanced detectors are those included in the so-called internet of things (IOT). When properly configured, these detectors enable remote transmission of messages to the mobile phone, informing the user, during the absence in the facility where the detector is installed, that the detector has been triggered and alarms or alarmed about a threat. Optionally, detectors with a built-in light source can also, for example, illuminate the path to the nearest exit (most often found in two-sensor detectors - detecting smoke in addition to $\mathrm{co}$ ). Regardless of the additional functions of the device, it should be remembered that the detector's primary task is to monitor the concentration of carbon monoxide in the rooms where it has been installed. So where to install carbon monoxide detectors? As a minimum, the installation should apply to communication routes (near the rooms), and in the optimal variant, close to places where potential carbon monoxide emissions may occur. The detector should always be installed in accordance with the recommendations of its manufacturer. A general recommendation is to install the detector on the walls at eye level. However, it is essential to remember not to install carbon monoxide detectors near windows, vents, or air conditioners.

\section{Polish legislation}

\section{Smoke detector}

In Poland, the introduction to the market of both smoke detectors and carbon monoxide detectors is regulated by the Act on construction products [7]. The placing on the market or making available on the national market of construction products - in this case a smoke detector - is described in Chapter 2 of the Act of 24 August 1991 on fire protection [5]. Pursuant to Art. $5 \mathrm{sec} .1$ "a construction product covered by a harmonized standard or compliant with the European Technical Assessment issued for it may be placed on the market or made available on the national market only in accordance with Regulation No. 305/2011". This article applies to smoke detectors for which a harmonized standard EN 14604: 2005+AC:2008 Smoke alarm wymianę akumulatora w momencie krytycznym, zapewniając ciągłość ochrony i poprawne działanie czujki. Analogicznie do zaleceń w zakresie czujek dymu wymiana baterii w czujkach tlenku węgla powinna być dokonywana każdorazowo zgodnie z instrukcją producenta. Oferowane obecnie na rynku modele czujek tlenku węgla są wyposażone w panele ciekłokrystaliczne, za pomocą których użytkownik urządzenia ma możliwość bieżącego kontrolowania stężenia tlenku węgla (CO). Modele wyposażone w panel umożliwiają również odczyt stężenia CO podczas ostatniej aktywacji alarmu. Jest to możliwe dzięki wbudowanej wewnętrznie pamięci. Dzięki funkcji archiwizowania pomiarów użytkownik ma możliwość kontroli pracy urządzenia podczas nieobecności w obiekcie, w którym zainstalowano czujnik. W rezultacie, nawet w takiej sytuacji, każdy aktywowany wówczas alarm zostanie zauważony, co stanowi ważną informację dla użytkownika, jak również potwierdza zasadność dozorowania pomieszczenia pod kątem zagrażających życiu i zdrowiu stężeń CO w tym obiekcie czy konkretnym pomieszczeniu. Do najbardziej zaawansowanych pod względem technologicznym detektorów należą te zaliczane do tzw. internetu rzeczy (ang. internet of things - loT). Detektory te po właściwej konfiguracji umożliwiają zdalną transmisję wiadomości na telefon komórkowy, informując użytkownika podczas nieobecności w obiekcie, w którym zainstalowano czujkę, że detektor został wzbudzony i alarmuje bądź alarmował o zagrożeniu. Opcjonalnie, czujki z wbudowanym źródłem światła mogą również np. podświetlać drogę do najbliższego wyjścia (spotykane najczęściej w czujkach dwudetektorowych - wykrywających oprócz CO również dym). Niezależnie od dodatkowych funkcji urządzenia należy pamiętać, że podstawowym zadaniem czujki jest monitorowanie stężenia tlenku węgla w pomieszczeniach, w których została ona zainstalowana. Gdzie zatem instalować czujki tlenku węgla? W wariancie minimalnym instalacja powinna dotyczyć ciągów komunikacyjnych (w pobliżu pokoi), a w wariancie optymalnym w pobliżu miejsc, gdzie może dojść do potencjalnej emisji tlenku węgla. Czujka zawsze powinna być zainstalowana zgodnie z zaleceniami jej producenta. Ogólne zalecenie to zainstalowanie czujki na ścianach na wysokości wzroku. Należy jednak pamiętać, aby nie instalować czujek tlenku węgla w pobliżu okien, wyciągów wentylacyjnych lub klimatyzatorów.

\section{Prawo polskie}

\section{Autonomiczna czujka dymu}

W Polsce wprowadzenie do obrotu zarówno autonomicznych czujek dymu, jak i autonomicznych czujek tlenku węgla jest regulowane przez ustawę o wyrobach budowlanych [7].Wprowadzenie do obrotu lub udostępnianie na rynku krajowym wyrobów budowlanych - w tym wypadku autonomicznej czujki dymu zostało opisane w rozdz. 2 ustawy z dnia 24 sierpnia $1991 \mathrm{r}$. o ochronie przeciwpożarowej [5]. Zgodnie z art. 5, ust. 1 „wyrób budowlany objęty normą zharmonizowaną lub zgodny z wydaną dla niego europejską oceną techniczną, może być wprowadzony do obrotu lub udostępniany na rynku krajowym wyłącznie zgodnie z rozporządzeniem nr 305/2011." Artykuł ten stosuje się do autonomicznych czujek dymu, dla których opracowano normę 
devices has been developed, the equivalent of which, published by the Polish Committee for Standardization, is a Polish Standard PN-EN 14604:2006 [1]. The Regulation 305/2011 [6] referred to in the Act establishes harmonized conditions for the marketing of construction products throughout the European Union. Pursuant to Art. 4 of this regulation, "when a construction product is covered by a harmonised standard or conforms to a European Technical Assessment which has been issued for it, the manufacturer shall draw up a declaration of performance when such a product is placed on the market". By drawing up the declaration of performance (DoP), the manufacturer assumes sole responsibility for the compliance of the product with the performance properties declared in the DoP. Unless there are objective indications to the contrary, Member States shall presume that the manufacturer's declaration of performance is accurate and reliable. However, issuing such a declaration must be preceded by the process of assessment and verification of constancy of performance. System 1 is used for smoke detectors. In this system, the declaration of performance of the essential characteristics of the construction product is made by the manufacturer on the basis of the following data (in accordance with Annex V to Regulation 305/2011):

1. The manufacturer shall carry out:

- factory production control,

- further testing of samples taken at the factory by the manufacturer in accordance with the prescribed test plan.

2. The notified product certification body shall issue the certificate of constancy of performance of the product on the basis of:

- determination of the product type on the basis of type testing (including sampling), type calculation, tabulated values or descriptive documentation of the product,

- initial inspection of the manufacturing plant and of factory production control,

- continuous surveillance, assessment and evaluation of factory production control.

Therefore, it is an extremely restrictive system, which thus ensures that all detectors in the European Union meet the same minimum requirements, which include not only tests related to durability and operational reliability, but also tests of nominal commissioning conditions and operational reliability (the harmonized standard lists as many as 42 tests in individual groups, which should be subjected to product samples). Apart from the legal provisions described above, there are no other regulations in Poland regarding the application or, for example, the obligation to install smoke detectors in the selected facilities.

\section{Carbon monoxide detector}

As mentioned above, in Poland, the placing on the market of carbon monoxide detectors is regulated by the Act on construction products [7]. Placing on the market or making available on the national market carbon monoxide detectors is regulated by Art. $5 \mathrm{sec}$. 2 of the same act, according to which "a construction product not covered by a harmonized standard, for which the zharmonizowaną EN 14604:2005+AC:2008 Autonomiczne czujki dymu, której odpowiednikiem opublikowanym przez Polski Komitet Normalizacyjny jest Polska Norma PN-EN 14604:2006 [1]. Przywołane w ustawie rozporządzenie 305/2011 [6] ustanawia zharmonizowane warunki wprowadzania do obrotu wyrobów budowlanych w całej Unii Europejskiej. Zgodnie z art. 4 tego rozporządzenia „jeżeli wyrób budowlany objęty jest normą zharmonizowaną lub jest zgodny z wydaną dla niego europejską oceną techniczną, producent sporządza deklarację właściwości użytkowych (DWU) przy wprowadzeniu takiego wyrobu do obrotu". Sporządzając deklarację właściwości użytkowych producent przyjmuje na siebie wyłączną odpowiedzialność za zgodność wyrobu z zadeklarowanymi w DWU właściwościami użytkowymi. Jeżeli nie istnieją obiektywne przesłanki, że jest inaczej, państwa członkowskie przyjmują, że deklaracja właściwości użytkowych sporządzona przez producenta jest dokładna i wiarygodna. Wystawienie jednak takiej deklaracji musi zostać poprzedzone procesem oceny i weryfikacji stałości właściwości użytkowych. Dla autonomicznych czujek dymu stosuje się system 1. W tym systemie deklaracja właściwości użytkowych zasadniczych charakterystyk wyrobu budowlanego dokonywana jest przez producenta na podstawie następujących danych (zgodnie z załącznikiem V do rozporządzenia 305/2011):

1. Producent przeprowadza:

- zakładową kontrolę produkcji,

- dalsze badania próbek pobranych w zakładzie przez producenta zgodnie $z$ ustalonym planem badań.

2. Notyfikowana jednostka certyfikująca wyrób wydaje certyfikat stałości właściwości użytkowych wyrobu na podstawie:

- ustalenia typu wyrobu w oparciu o badania (w tym pobieranie próbek), obliczenia, tabelaryczne wartości lub opisową dokumentację wyrobu,

- wstępnej inspekcji zakładu produkcyjnego i zakładowej kontroli produkcji,

- stałego nadzoru, oceny i ewaluacji zakładowej kontroli produkcji.

Jest to zatem system niezwykle restrykcyjny, który tym samym zapewnia, że wszystkie czujki na terenie Unii Europejskiej spełniają te same minimalne wymagania, wśród których znajdują się nie tylko badania związane z trwałością i niezawodnością działania, ale również badania nominalnych warunków uruchomienia czy niezawodności eksploatacyjnej (norma zharmonizowana wymienia w poszczególnych grupach aż 42 badania, którym należy poddać próbki wyrobu). Poza przepisami prawa, które opisano powyżej, w zakresie stosowania czy np. obowiązku instalacji w wybranych obiektach autonomicznych czujek dymu nie istnieją w Polsce inne regulacje.

\section{Autonomiczna czujka tlenku węgla}

Jak wspomniano powyżej, w Polsce wprowadzenie do obrotu autonomicznych czujek tlenku węgla regulowane jest przez ustawę o wyrobach budowlanych [7]. Wprowadzenie do obrotu lub udostępnianie na rynku krajowym autonomicznych czujek tlenku węgla regulowane jest przez art. 5, ust. 2 tejże ustawy, zgodnie z którym „wyrób budowlany nieobjęty normą zharmonizowaną, dla której zakończył 
period of coexistence referred to in Art. $17 \mathrm{sec} .5$ of Regulation No. 305/2011, and for which the European Technical Assessment has not been issued, may be placed on the market or made available on the national market, if it has been marked with a construction mark, the specimen of which is set out in Annex 1 to the Act".

The application of paragraph 2 of Art. 5 mentioned above for a group of products used in a very similar scope, i.e. the safety of facility users, results from the fact that despite the development of a European standard EN 50291-1:2018 Gas detectors - Electrical apparatus for the detection of carbon monoxide in domestic premises - Part 1: Test methods and performance requirements (the Polish equivalent is the Polish Standard PN-EN 50291-1:2018-06+AC:2021-03E) [4], the standard in question has not been published in the Official Journal of the European Union, therefore it does not have the status of a harmonized standard, which is essential for European certification. Therefore, in order to legally place a product such as a carbon monoxide detector on the market, it must be marked with a construction mark. It is a process similar in form to the European process described above, which is regulated in the Polish regulation, which is the Regulation of the Minister of Infrastructure and Construction on the method of declaring the performance of construction products and the method of marking them with a construction mark [8]. It should be emphasized here that, in accordance with the content of the subsequent amendments to the discussed provision, the obligation to label carbon monoxide detectors with the construction mark B was not created until 1 January 2021. From that date, the manufacturers must also issue national declarations of performance, which are the equivalent of (European) declarations of performance. In the national system of assessment and verification of constancy of performance, the manufacturer's activities include, respectively, determining the type of construction product and carrying out:

- factory production control,

- testing of samples taken at the factory by the manufacturer in accordance with the prescribed test plan.

On the other hand, the activities of the Accredited Certification Body related to assessment and verification, include:

- assessment of the performance of a construction product on the basis of testing samples taken by the certification body, calculations, tabular values or descriptive documentation of this product,

- initial inspection of the manufacturing plant and of factory production control,

- issuing a national certificate of constancy of performance,

- continuous surveillance, assessment and evaluation of factory production control.

As can be seen from the above comparison, Polish law does not significantly differ from the provisions adopted in the European Union related to the marketing of products in the event that it is impossible to perform the so-called European certification. Unfortunately, as in the case of smoke detectors, in Poland these are the only regulations related to these products and there are no other national regulations that would require the use of carbon monoxide detectors in areas where there is a risk it can appear. się okres koegzystencji, o którym mowa w art. 17 ust. 5 rozporządzenia $\mathrm{nr} 305 / 2011$, i dla którego nie została wydana europejska ocena techniczna, może być wprowadzony do obrotu lub udostępniany na rynku krajowym, jeżeli został oznakowany znakiem budowlanym, którego wzór określa załącznik nr 1 do ustawy".

Stosowanie ustępu 2 wymienionego powyżej art. 5 dla grupy wyrobów znajdujących zastosowanie $w$ bardzo zbliżonym zakresie tj. bezpieczeństwo użytkowników obiektów wynika z faktu, że pomimo opracowania normy europejskiej EN 50291-1:2018 Wykrywacze gazu - Urządzenia elektryczne do wykrywania tlenku węgla w pomieszczeniach domowych - Część 1: Metody badań i wymagania eksploatacyjne (polskim odpowiednikiem jest Polska Norma PN-EN 50291-1:2018-06+AC:2021-03E) [4], to przedmiotowa norma nie została opublikowana w Dzienniku Urzędowym Unii Europejskiej, w związku z czym nie posiada ona, kluczowego dla certyfikacji europejskiej, statusu normy zharmonizowanej. Zatem, aby wprowadzić legalnie wyrób, jakim jest autonomiczna czujka tlenku węgla, należy oznakować go znakiem budowlanym. Jest to proces w swojej formie podobny do opisanego powyżej procesu europejskiego, który uregulowano w polskim przepisie, jakim jest rozporządzenie Ministra Infrastruktury i Budownictwa w sprawie sposobu deklarowania właściwości użytkowych wyrobów budowlanych oraz sposobu znakowania ich znakiem budowlanym [8]. Podkreślenia w tym miejscu wymaga fakt, że zgodnie z treścią kolejnych nowelizacji omawianego przepisu obowiązek znakowania autonomicznych czujek tlenku węgla znakiem budowlanym B powstał dopiero 1 stycznia 2021 roku. Od tego dnia producenci muszą również wystawiać krajowe deklaracje właściwości użytkowych, które są odpowiednikiem (europejskich) deklaracji właściwości użytkowych. W krajowym systemie oceny i weryfikacji stałości właściwości użytkowych działania producenta obejmują odpowiednio określenie typu wyrobu budowlanego oraz prowadzenie:

- zakładowej kontroli produkcji,

- badań próbek pobranych przez producenta w zakładzie produkcyjnym zgodnie $z$ ustalonym przez niego planem badań.

Działania Akredytowanej Jednostki Certyfikującej związane z oceną i weryfikacją obejmują natomiast:

- ocenę właściwości użytkowych wyrobu budowlanego na podstawie badań próbek pobranych przez jednostkę certyfikującą, obliczeń, tabelarycznych wartości lub opisowej dokumentacji tego wyrobu,

- przeprowadzenie wstępnej inspekcji zakładu produkcyjnego i zakładowej kontroli produkcji,

- wydanie krajowego certyfikatu stałości właściwości użytkowych,

- kontynuację nadzoru, oceny i ewaluacji zakładowej kontroli produkcji.

Jak wynika z powyższego porównania prawo polskie nie odbiega w sposób znaczący od przyjętych w Unii Europejskiej przepisów związanych z wprowadzaniem do obrotu wyrobów w przypadku, gdy brak jest możliwości dokonania tzw. certyfikacji europejskiej. Niestety, analogicznie jak w przypadku autonomicznych czujek dymu, w Polsce są to jedyne przepisy związane $z$ tymi wyrobami i nie istnieją inne regulacje krajowe, które nakazywałyby stosowanie autonomicznych czujek tlenku węgla w przestrzeniach zagrożonych jego powstawaniem. 


\section{European legislation}

As already mentioned, when describing this scope of European regulations, in the area related to the placing on the market of smoke detectors, Regulation 305/2011 [6] applies. In Germany and France, the introduction of smoke detectors to the market must be preceded by the same process as the one that is also in force in Poland. However, the issue related to the obligation to install this type of detectors looks completely different. In Germany, the obligation to detect smoke is regulated by the building regulations of the individual federal states, which are left with the decision to introduce an obligation to detect smoke. In 15 out of 16 federal states, the obligation to detect smoke applies to both new and existing buildings. Saxony is the only federal state that did not require smoke detectors to be installed in existing buildings (in terms of existing buildings on 1 January 2016). From 1 January 2016, all newly constructed buildings, also in Saxony, are equipped with smoke detectors. In all federal states, the cost of installing and maintaining the detector is borne by the owner or tenant. On the website of one of the manufacturers of smoke detectors, regulations in this area, which have been presented in a way that is more understandable to end-users can be found [9]. One can search for a specific federal state on the website and by answering further questions can see how many smoke detectors are required. Simple questions are presented below, on the basis of which the website generates the required number of detectors, with a clear reservation that, for example, in the case of rooms larger than $60 \mathrm{~m}^{2}$ or corridors over $15 \mathrm{~m}$ long, the number of detectors must be greater.

1. How many bedrooms and guest rooms do you have?

2. How many children's rooms (children's and teenagers' rooms) do you have?

3. How many hallways, stairways and passages are used as escape routes?

In France, since 8 March 2015, houses and apartments have been required to be equipped with at least one smoke detector and, in accordance with EN 14604, it is the property of the owner of the facility. The tenant, on the other hand, takes responsibility for maintenance and possible repairs. If the owner of the apartment does not meet this requirement, the insurer may add an additional fee to the policy or refuse to cover the cost of damage in the event of a fire.

Another country in Europe that has legally regulated smoke detector installations is Great Britain - specifically England. The regulations of this country go a step further than the previously discussed regulations in force in Germany and France. From 1 October 2015, the installation of smoke detectors and carbon monoxide detectors is mandatory if there is a potential source of carbon monoxide in the room, e.g. a coal or wood-fired stove/ fireplace. If the local housing authority finds that the law has been violated, it has the right to impose a fine that can be up to $£ 5,000$. Considering average earnings are around $€ 32,000$ a year, which translates to $£ 2,600$ a month, the penalty for not following the law to install and then maintain detectors in good condition appears to be economically painful.

\section{Prawo europejskie}

Tak jak już wspomniano, opisując ten zakres europejskich regulacji, w obszarze związanym z wprowadzeniem do obrotu autonomicznych czujek dymu ma zastosowanie rozporządzenie 305/2011 [6]. W Niemczech i we Francji wprowadzenie do obrotu czujek dymu musi być poprzedzone takim samym procesem, jak ten który obowiązuje również w Polsce. Zupełnie inaczej wygląda natomiast kwestia związana z obowiązkiem instalacji tego typu detektorów. W Niemczech obowiązek wykrywania dymu jest uregulowany w przepisach budowlanych poszczególnych krajów związkowych, którym pozostawiono decyzję odnośnie wprowadzenia obowiązku wykrywania dymu. W 15 z 16 krajów związkowych obowiązek wykrywania dymu dotyczy zarówno nowych, jak i istniejących budynków. Saksonia jest jedynym krajem związkowym, który nie wymagał instalowania czujników dymu w istniejących budynkach (w rozumieniu budynków istniejących na dzień 1 stycznia 2016 roku). Od dnia 1 stycznia 2016 roku wszystkie nowo powstałe budynki, również w Saksonii, są wyposażane w czujki dymu. We wszystkich krajach związkowych koszt związany z instalacją i konserwacją czujki ponosi właściciel obiektu lub jego dzierżawca. Na stronie internetowej jednego z producentów czujek dymu można zapoznać się z przepisami w tym zakresie, które zostały przedstawione w sposób bardziej zrozumiały dla użytkowników końcowych [9]. Można tam wyszukać dany kraj związkowy i odpowiadając na kolejne pytania sprawdzić, ile czujek dymu jest wymaganych. Poniżej przedstawiono proste pytania, na podstawie których strona generuje wymaganą liczbę czujek, z wyraźnym zastrzeżeniem, że np. w przypadku pokoi większych niż $60 \mathrm{~m}^{2}$ czy korytarzy o długości ponad $15 \mathrm{~m}$ liczba czujek musi być większa.

1. Ile masz sypialni i pokoi gościnnych?

2. Ile masz pokoi dziecięcych (pokoje dzieci i nastolatków)?

3. Ile korytarzy, klatek schodowych i przejść jest wykorzystywanych jako drogi ewakuacyjne?

We Francji od 8 marca 2015 r. istnieje obowiązek wyposażania domów i mieszkań w co najmniej jeden detektor dymu i zgodnie z normą EN 14604 należy on do właściciela obiektu. Najemca natomiast bierze odpowiedzialność za konserwację i ewentualne naprawy. Jeżeli właściciel obiektu mieszkalnego nie spełni tego wymagania, ubezpieczyciel może doliczyć dodatkową opłatę do polisy lub odmówić pokrycia kosztów szkody w przypadku pożaru.

Kolejnym krajem w Europie, w którym uregulowano prawnie instalacje czujek dymu, jest Wielka Brytania - konkretnie Anglia. Przepisy tego kraju idą o krok dalej niż omawiane wcześniej obowiązujące w Niemczech i we Francji. Od 1 października 2015 roku instalowanie czujek dymu oraz czujek tlenku węgla jest obowiązkowe, jeśli w pomieszczeniu znajduje się potencjalne jego źródło np. piec/kominek opalany węglem lub drewnem. Jeżeli lokalny urząd mieszkaniowy (ang. local housing authority) dowiedzie, że przepisy zostały naruszone, wówczas ma on prawo nałożyć karę pieniężną, która może wynieść do pięciu tysięcy funtów. Mając na uwadze, że średnia zarobków wynosi około 32 tysiące funtów rocznie, co przekłada się na 2600 funtów miesięcznie, to kara za nieprzestrzeganie prawa związanego z obowiązkiem instalacji, a następnie utrzymywania czujek w poprawnym stanie, wydaje się być ekonomicznie dotkliwa. 


\section{Detectors and the Integrated Qualification System in fire protection}

An equally important area of national regulations as the regulations on placing products on the market should be the aspect of the quality of services provided in fire protection, i.e. the area of standardization of services such as installation and maintenance of alarm detectors. This is an area that guarantees that services in this area are provided by people whose knowledge, competences and practical skills are at an appropriate level. The national regulations in this respect come down to insufficiently specified provisions of the Act on fire protection [5], in which in Art. 4 paragraph 2 it is stipulated that "activities in the field of fire protection may be performed by persons with appropriate qualifications". Unfortunately, this provision and other fire or technical and construction regulations do not specify the qualifications of persons who design, install and maintain (service) fire protection, including alarm detectors in buildings.

As shown in practice, including the processes of certification of fire protection installations or assessment and verification of fire safety of buildings, conducted by Centrum Naukowo-Badawcze Ochrony Przeciwpożarowej - Państwowy Instytut Badawczy (Scientific and Research Centre for Fire Protection - National Research Institute; CNBOP-PIB), no sufficiently specified, formal requirements and regulations regarding the qualifications for installation and fire protection maintenance adversely affects the quality of the provided services, which in fact directly translates into the level of fire safety of buildings. In order to face this unfavorable situation, in 2017 at CNBOP-PIB a work group was established in cooperation with experts from Instytut Badań Edukacyjnych (Educational Research Institute), whose aim was to use the tools offered by the Integrated Qualifications System (ZSK), i.e. developing new market qualifications related to fire safety. As a result of the cooperation, requirements were developed for the following market qualifications:

1. Installation and maintenance of alarm detectors: carbon monoxide, smoke, heat and gas.

2. Designing fire protection - voice alarm systems (DSO).

3. Designing fire protection - fire alarm systems (SSP) and control of fire protection devices.

4. Designing fire protection - fixed gas extinguishing systems (SUG-G).

5. Installation and maintenance of fire protection - voice alarm systems (DSO).

6. Installation and maintenance of fire protection - fire alarm systems (SSP) and control of fire protection devices.

7. Installation and maintenance of fire protection - fixed gas extinguishing systems (SUG-G).

The breakthrough moment for the undertaken work was May 2019, when the announcement of the Minister of the Interior and Administration of 7 May 2019 was published in Monitor Polski on the inclusion of market qualifications for the installation and maintenance of alarm detectors: carbon monoxide, smoke, heat and gas and design, installation and maintenance of fire protection (SSP, DSO, SUG-G) to the Integrated Qualification System [10].

\section{Czujki a Zintegrowany System Kwalifikacji w ochronie przeciwpożarowej}

Równie istotnym obszarem regulacji krajowych jak regulacje dotyczące wprowadzenia wyrobów do obrotu, powinien być aspekt dotyczący jakości usług świadczonych w ochronie przeciwpożarowej, czyli obszar standaryzacji takich usług jak montaż i konserwacja autonomicznych czujek. Jest to obszar gwarantujący, że usługi w tym zakresie świadczą osoby, których wiedza, kompetencje oraz umiejętności praktyczne są na właściwym poziomie. Krajowe przepisy w tym względzie sprowadzają się do niedostatecznie sprecyzowanych zapisów ustawy o ochronie przeciwpożarowej [5], w której w art. 4. ust. 2. określa się, że "Czynności z zakresu ochrony przeciwpożarowej mogą wykonywać osoby posiadające odpowiednie kwalifikacje". Niestety ten przepis oraz inne przepisy przeciwpożarowe czy techniczno-budowlane nie precyzują już, jakie kwalifikacje powinny posiadać osoby, które projektują, instalują i konserwują (serwisują) zabezpieczenia przeciwpożarowe $w$ tym autonomiczne czujki w obiektach budowlanych.

Jak pokazuje praktyka stosowania, w tym prowadzone przez Centrum Naukowo-Badawcze Ochrony Przeciwpożarowej - Państwowy Instytut Badawczy (CNBOP-PIB) procesy certyfikacji instalacji przeciwpożarowych czy oceny i weryfikacji bezpieczeństwa pożarowego obiektów budowlanych, brak dostatecznie sprecyzowanych, formalnych wymagań i regulacji dotyczących kwalifikacji do montażu i konserwacji zabezpieczeń przeciwpożarowych wpływa niekorzystnie na jakość świadczonych usług, co w rzeczywistości bezpośrednio przekłada się na poziom bezpieczeństwa pożarowego obiektów budowlanych. Chcąc wyjść naprzeciw tej niekorzystnej sytuacji w CNBOP-PIB w 2017 roku został powołany zespół zadaniowy we współpracy z ekspertami z Instytutu Badań Edukacyjnych, którego celem stało się wykorzystanie narzędzi, jakie oferuje Zintegrowany System Kwalifikacji (ZSK), tj. opracowanie nowych kwalifikacji rynkowych związanych z bezpieczeństwem pożarowym. W wyniku prac zespołu zostały opracowane wymagania dla następujących kwalifikacji rynkowych:

1. Montaż i konserwacja autonomicznych czujek: tlenku węgla, dymu, ciepła i gazu.

2. Projektowanie zabezpieczeń przeciwpożarowych - dźwiękowe systemy ostrzegawcze (DSO).

3. Projektowanie zabezpieczeń przeciwpożarowych - systemy sygnalizacji pożarowej (SSP) i sterowania urządzeniami przeciwpożarowymi.

4. Projektowanie zabezpieczeń przeciwpożarowych - stałe urządzenia gaśnicze gazowe (SUG-G).

5. Montaż i konserwacja zabezpieczeń przeciwpożarowych - dźwiękowe systemy ostrzegawcze (DSO).

6. Montaż i konserwacja zabezpieczeń przeciwpożarowych - systemy sygnalizacji pożarowej (SSP) i sterowania urządzeniami przeciwpożarowymi.

7. Montaż $i$ konserwacja zabezpieczeń przeciwpożarowych - stałe urządzenia gaśnicze gazowe (SUG-G).

Przełomowym momentem dla podjętych prac okazał się maj 2019 roku, kiedy to w Monitorze Polskim opublikowano obwieszczenie Ministra Spraw Wewnętrznych i Administracji z dnia 
In July of the same year, CNBOP-PIB, by the decision of the Minister of Internal Affairs and Administration, obtained the status of a Certifying Authority (IC) for new market qualifications included in the ZSK system [11].

For the announced market qualifications for the installation and maintenance of carbon monoxide, smoke, heat and gas alarm detectors, the levels of the Polish Qualification Framework (PRK) and the European Qualification Framework have been assigned, i.e. installation and maintenance of alarm detectors: carbon monoxide, smoke, heat and gas - 2nd level of PRK, symbol PRK2.

The process, currently implemented at the Institute, of validating the market qualifications for the design, installation and maintenance of fire protection, on the basis of the decision of the Minister of the Ministry of Interior and Administration of 9 July 2019 [11], will be conducted by CNBOP-PIB in accordance with the diagram in Figure 5.

The validation process carried out by CNBOP-PIB Certifying Authority is distinguished by the following stages:

- identifying and informing,

- registration,

- verification of learning outcomes.

Identifying and informing is a stage in the validation process in which the candidate, based on the information provided on the website, independently diagnoses his competence in the installation and maintenance of alarm detectors. The provided information includes: regulations, content of declarations, information about a given PRK2 level, validation scheme, contact details, application form, link to the announcement and an extract of learning outcomes from the description of the qualification, information about the previously required qualifications, information about potential validation dates, information on fees, etc. This stage should end with the registration of the candidate for the appropriate date of verification of the learning outcomes of set 1 or 2 of the qualifications or the development of a further learning plan: self-education or during a dedicated training.

Registration is a stage in the validation process in which the candidate, already in the registration system available on the website after registration, selects the date of validation of learning outcomes, respectively, from set 1 and 2 for the market qualification "Installation and maintenance of alarm detectors: carbon monoxide, smoke, heat and gas". Validation of the learning outcomes from set 2 is only possible after passing the learning outcomes from set 1 of the market qualification.

Verification of learning outcomes is a validation stage in which the candidate checks and confirms the learning outcomes required for a qualification. The verification of learning outcomes includes a theoretical part and a practical part. To verify the learning outcomes for the market qualification for the installation and maintenance of alarm detectors: carbon monoxide, smoke, heat and gas, only the following verification method is allowed - theoretical knowledge test for set 1, i.e. "Preparation for installation and maintenance of fire safety monitoring devices". As part of this set, the person taking the exam defines issues related to fire hazards, flammable gases and carbon monoxide, as well as the current legal status regarding the installation and maintenance of alarm detectors: carbon monoxide, smoke, heat and gas. The
7 maja 2019 r. w sprawie włączenia kwalifikacji rynkowych dotyczących montażu i konserwacji autonomicznych czujek: tlenku węgla, dymu, ciepła i gazu oraz projektowania, montażu i konserwacji zabezpieczeń przeciwpożarowych (SSP, DSO, SUG-G) do Zintegrowanego Systemu Kwalifikacji [10]. W lipcu tego samego roku CNBOP-PIB na mocy decyzji Ministra Spraw Wewnętrznych i Administracji otrzymało status Instytucji Certyfikującej (IC) dla nowych, włączonych do sytemu ZSK kwalifikacji rynkowych [11].

Dla ogłoszonych kwalifikacji rynkowych dotyczących montażu i konserwacji autonomicznych czujek tlenku węgla, dymu, ciepła i gazu zostały przypisane poziomy Polskiej Ramy Kwalifikacji i Europejskich Ram Kwalifikacji tj. montaż i konserwacja autonomicznych czujek: tlenku węgla, dymu, ciepła i gazu - 2 poziom PRK, ozn. PRK2.

Wdrażany obecnie $w$ Instytucie proces walidacji kwalifikacji rynkowych dotyczących projektowania, montażu i konserwacji zabezpieczeń przeciwpożarowych na podstawie decyzji Ministra MSWiA z dnia 9 lipca 2019 r. [11] będzie prowadzony przez CNBOP-PIB zgodnie ze schematem zamieszczonym na rycinie 5 .

Sam proces walidacji realizowany przez Instytucję Certyfikującą CNBOP-PIB wyróżnia się następującymi etapami:

- identyfikowanie i informowanie,

- rejestracja,

- weryfikacja efektów uczenia się.

Identyfikowanie i informowanie to etap w procesie walidacji, w którym kandydat samodzielnie na podstawie informacji zamieszczonych na stronie internetowej diagnozuje swoje kompetencje dotyczące montażu i konserwacji autonomicznych czujek. Udostępniane informacje to między innymi: regulamin, treść oświadczeń, informacja dotycząca danego poziomu PRK2, schemat walidacji, dane kontaktowe, dane formularza zgłoszeniowego, link do obwieszczenia i wyciąg efektów uczenia się z opisu kwalifikacji, informacja o wymaganych wcześniej uzyskanych kwalifikacjach, informacja o potencjalnych terminach przeprowadzenia walidacji, informacja o opłatach, itd. Etap ten powinien zakończyć się rejestracją kandydata na odpowiedni termin weryfikacji efektów uczenia się zestawu 1,2 kwalifikacji lub opracowaniem planu dalszego uczenia się: samodzielnie lub na dedykowanym szkoleniu. Etap identyfikowania i informowania może być wspierany przez doradcę walidacyjnego.

Rejestracja to etap w procesie walidacji, w którym kandydat już w systemie rejestracyjnym udostępnionym na stronie internetowej po zarejestrowaniu się wybiera termin walidacji efektów uczenia się odpowiednio z zestawu 1 i 2 dla kwalifikacji rynkowej „Montaż $i$ konserwacja autonomicznych czujek: tlenku węgla, dymu, ciepła i gazu". Walidacja efektów uczenia się z zestawu 2 jest możliwa tylko po zaliczeniu efektów uczenia się z zestawu 1 kwalifikacji rynkowej.

Weryfikacja efektów uczenia się to etap walidacji, w którym kandydat sprawdza i potwierdza wymagane dla kwalifikacji efekty uczenia się. Weryfikacja efektów uczenia się obejmuje część teoretyczną i część praktyczną. Do weryfikacji efektów uczenia się dla kwalifikacji rynkowej dotyczącej montażu i konserwacji autonomicznych czujek: tlenku węgla, dymu, ciepła i gazu dopuszcza się zastosowanie wyłącznie następującej metody weryfikacji - teoretyczny test wiedzy dla zestawu $1 \mathrm{tj}$. „Przygotowanie do montażu i konserwacji urządzeń monitorujących bezpieczeństwo pożarowe". W ramach tego zestawu osoba przystępująca do egzaminu charakteryzuje zagadnienia związane z zagrożeniami pożarowymi, gazami palnymi oraz 


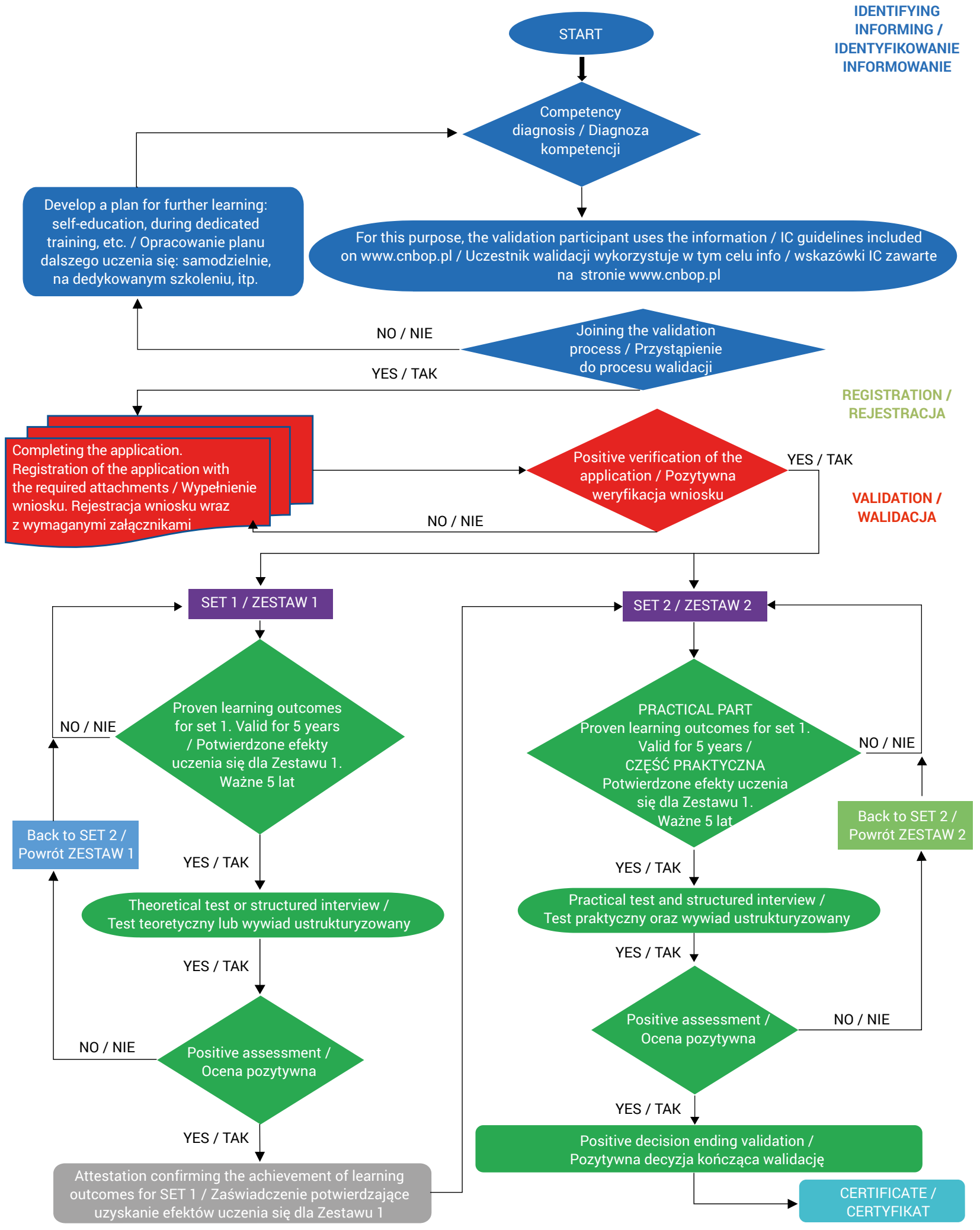

Figure 5. Validation scheme for the market qualification "Installation and maintenance of alarm detectors: carbon monoxide, smoke, heat and gas" Rycina 5. Schemat walidacji dla kwalifikacji rynkowej „Montaż i konserwacja autonomicznych czujek: tlenku węgla, dymu, ciepła i gazu”

Source: Own elaboration.

Źródło: Opracowanie własne. 
verification criteria for the listed learning outcomes for set 1 are the following skills of the participant:

- discusses fire hazards in homes, recreational vehicles and similar objects, including recreational boats,

- discusses the risks associated with the occurrence of flammable gases: natural gas, LPG and carbon monoxide,

- discusses the principles of reacting in the event of a fire,

- discusses the types and applications of portable fire fighting equipment,

- characterizes the types of alarm detectors: carbon monoxide, smoke, heat and gas,

- discusses the principles of self-evacuation from endangered rooms,

- describes additional options for alarming about a threat (communication between alarm detectors, communication within the alarm system, communication via local wi-fi or bluetooth),

- discusses the current legal regulations regarding the principles of health and safety, environmental protection regarding the installation and maintenance of alarm detectors: carbon monoxide, smoke, heat and gas,

- discusses the labeling of alarm detectors: carbon monoxide, smoke, heat and gas,

- discusses the rules of handling used electrical and electronic equipment, including alarm detectors: carbon monoxide, smoke, heat and gas.

The test of practical skills is the verification method for the second set of required learning outcomes. As part of set 2 "Installation and maintenance of alarm detectors: carbon monoxide, smoke, heat and gas', the examiner confirms that he or she has the following skills: installs and maintains an alarm detector. carbon monoxide, gas, smoke and heat. The accepted criteria for the verification of these skills are the following skills of the participant:

- checks the correctness of the order during an on-site inspection in terms of the possible sources of threats,

- determines the location of the installation of a detector,

- prepares the detector for operation, including the detector test,

- installs the detector,

- instructs the user to proceed in the event of an alarm triggered by a detector. extinguishing all fire sources, turning off gas devices, not turning on or off all electrical devices, including batteries, closing the gas valve, opening doors and windows, evacuation, calling for help, calling service to check the device, causing the alarm,

- describes possible disturbances in the operation of the detector, including mains power failure,

- instructs the user on the principles of proper use, including checking the detector's readiness and its maintenance,

- describes the activities necessary for proper maintenance of the detector.

The document confirming the granting of the qualifications "Installation and maintenance of alarm detectors: carbon monoxide, smoke, heat and gas" is a state certificate, which is valid indefinitely. tlenkiem węgla, a także charakteryzuje aktualny stan prawny dotyczący montażu i konserwacji autonomicznych czujek: tlenku węgla, dymu, ciepła i gazu. Kryteriami weryfikacji wymienionych efektów uczenia dla zestawu 1 stanowią poniższe umiejętności uczestnika:

- omawia zagrożenia pożarowe występujące w pomieszczeniach domowych, pojazdach rekreacyjnych i podobnych obiektach $w$ tym łodziach rekreacyjnych,

- omawia zagrożenia związane z wystąpieniem gazów palnych: gazu ziemnego, LPG oraz tlenku węgla,

- omawia zasady reagowania w przypadku powstania pożaru,

- omawia rodzaje i zastosowanie podręcznego sprzętu gaśniczego,

- charakteryzuje rodzaje autonomicznych czujek: tlenku węgla, dymu, ciepła i gazu,

- omawia zasady samoewakuacji z zagrożonych pomieszczeń,

- opisuje dodatkowe możliwości alarmowania o zagrożeniu (komunikacja pomiędzy czujkami autonomicznymi, komunikacja w ramach systemu alarmowego, komunikacja poprzez lokalną sieć wi-fi lub bluetooth),

- omawia aktualne przepisy prawa regulujące zasady BHP, ochrony środowiska dotyczące montażu oraz konserwacji autonomicznych czujek: tlenku węgla, dymu, ciepła i gazu,

- omawia sposób oznakowania autonomicznych czujek: tlenku węgla, dymu, ciepła i gazu,

- omawia zasady postępowania ze zużytym sprzętem elektrycznym i elektronicznym, w tym autonomicznymi czujnikami: tlenku węgla, dymu, ciepła i gazu.

Metodą weryfikacji dla drugiego zestawu wymaganych efektów uczenia się jest test umiejętności praktycznych. W ramach zestawu 2 "Montaż i konserwacja autonomicznych czujek: tlenku węgla, dymu, ciepła i gazu" osoba egzaminowana potwierdza posiadanie następujących umiejętności: montuje i konserwuje autonomiczną czujkę tlenku węgla, gazu, dymu i ciepła. Przyjętymi kryteriami weryfikacji tych umiejętności są wymienione poniżej umiejętności uczestnika:

- sprawdza prawidłowość zamówienia w czasie wizji lokalnej pod względem występujących źródeł zagrożeń,

- ustala lokalizację montażu czujek,

- przygotowuje czujkę do pracy, w tym przeprowadza test czujki,

- montuje czujkę,

- instruuje użytkownika o postępowaniu w sytuacji alarmu wywołanego przez czujkę: zgaszenie wszystkich źródeł ognia, wyłączenie urządzeń gazowych, niewłączanie lub wyłączenie wszystkich urządzeń elektrycznych w tym na baterie, zamknięcie zaworu gazu, otwarcie drzwi i okien, ewakuacja, wezwanie pomocy, wezwanie serwisu do urządzenia, będącego przyczyną alarmu,

- opisuje możliwe zakłócenia pracy czujki, w tym brak zasilania sieciowego,

- instruuje użytkownika o zasadach prawidłowej eksploatacji, w tym sprawdzenia gotowości i konserwacji czujki,

- omawia czynności niezbędne dla prawidłowej konserwacji czujki.

Dokumentem potwierdzającym nadanie kwalifikacji „Montaż i konserwacja autonomicznych czujek: tlenku węgla, dymu, ciepła i gazu" jest państwowy certyfikat, który jest ważny bezterminowo. 


\section{Summary}

The qualifications and competences of personnel performing activities for the fire safety of buildings, including the installation and maintenance of alarm detectors, are extremely important and require their proper management and formal confirmation. The basic requirement is a sufficiently high level of qualifications and competences of the people offering their services in this area, the lack of which in the national legislation was one of the reasons for insufficiently equipping households in Poland with alarm detectors. On the basis of studies commissioned by the Ministry of the Interior and Administration in 2016 [12], it was found that only $18 \%$ of households, according to the declarations of the respondents, are equipped with an alarm detector. At the same time, on the basis of the same studies, it was discovered that nearly half of the respondents declared that they were able to sensually recognize carbon monoxide, which in fact is an odorless and colorless substance, i.e. physically unidentifiable by human senses. The selected conclusions from the conducted studies, which were the motivation to start a project at CNBOPPIB in the direction of defining the quality standards of services provided in fire protection, missing in the applicable provisions of law, are presented in the table below.

\section{Podsumowanie}

Kwalifikacje i kompetencje personelu wykonującego czynności na rzecz bezpieczeństwa pożarowego obiektów budowlanych, w tym montaż i konserwacja czujek autonomicznych, są niezwykle ważne i wymagają właściwego zarządzania nimi oraz ich formalnego potwierdzania. Podstawowym wymogiem jest dostatecznie wysoki poziom kwalifikacji i kompetencji przez osoby oferujące swoje usługi w tym zakresie, których uprzedni brak w krajowym ustawodawstwie stanowił jedną z przyczyn niedostatecznego wyposażenia gospodarstw domowych w Polsce w autonomiczne czujki. Na podstawie badań przeprowadzonych na zlecenie Ministerstwa Spraw Wewnętrznych i Administracji w 2016 r. [12] stwierdzono, że zaledwie 18\% gospodarstw domowych według deklaracji respondentów jest wyposażonych w autonomiczną czujkę. Jednocześnie na podstawie tych samych badań stwierdzono, że blisko połowa badanych deklarowała, iż jest w stanie zmysłowo rozpoznać tlenek węgla, który w istocie jest substancją bezwonną i bezbarwną, czyli fizycznie nieidentyfikowalną za pomocą ludzkich zmysłów. Wybrane wnioski z przeprowadzonych badań, które stanowiły motywację do podjęcia prac w CNBOP-PIB w kierunku określenia brakujących w obowiązujących przepisach prawa standardów jakości świadczonych usług w ochronie przeciwpożarowej, przedstawiono w poniższej tabeli.

Table 1. Summary of research results regarding fire hazard, carbon monoxide poisoning and smoke Tabela 1. Podsumowanie wyników badania dotyczących zagrożenia pożarowego oraz zatruć tlenkiem węgla i dymem

\begin{tabular}{|c|c|c|c|}
\hline $\begin{array}{l}\text { Cause of fires / } \\
\text { Przyczyny pożarów }\end{array}$ & $\begin{array}{l}\text { Presence of carbon monoxide / } \\
\text { Obecność tlenku węgla (czadu) }\end{array}$ & $\begin{array}{c}\text { Fire prevention / } \\
\text { Zapobieganie pożarom }\end{array}$ & $\begin{array}{l}\text { Equipped with detectors / } \\
\text { Wyposażenie w czujniki }\end{array}$ \\
\hline $\begin{array}{l}51 \% \text { of the respondents } \\
\text { mention a short circuit or other } \\
\text { failure of the electrical system } \\
\text { as the most common cause of } \\
\text { fires, and every third ( } 36 \% \text { ) also } \\
\text { mention unintentional starting } \\
\text { of a fire / } 51 \% \text { respondentów } \\
\text { wymienia zwarcie lub inną } \\
\text { awarię instalacji elektrycznej } \\
\text { jako najczęstszą przyczynę } \\
\text { pożarów, a co trzeci ( } 36 \%) \\
\text { wskazuje również nieumyślne } \\
\text { zaprószenie ognia }\end{array}$ & $\begin{array}{l}41 \% \text { of the respondents declared the } \\
\text { ability to recognize carbon monoxide, } \\
\text { and such a declaration was made much } \\
\text { more often by inhabitants of rural areas } \\
\text { than large cities ( } 26 \% \text { of inhabitants of } \\
\text { large cities and } 48 \% \text { of rural residents) / } \\
41 \% \text { respondentów zadeklarowało umie- } \\
\text { jętność rozpoznania czadu, przy czym } \\
\text { deklaracja taka zdecydowanie częściej } \\
\text { składana była przez mieszkańców wsi } \\
\text { niż dużych miast ( } 26 \% \text { mieszkańców } \\
\text { dużych miast i } 48 \% \text { mieszkańców wsi) }\end{array}$ & $\begin{array}{l}45 \% \text { of the respondents appreciate } \\
\text { the role of smoke and carbon } \\
\text { monoxide detectors in fire pre- } \\
\text { vention / } \\
45 \% \text { respondentów docenia rolę } \\
\text { czujników dymu i czadu w zapo- } \\
\text { bieganiu pożarom }\end{array}$ & $\begin{array}{l}18 \% \text { and } 17 \% \text { of the respondents have } \\
\text { smoke and carbon monoxide detectors, } \\
\text { respectively / } \\
\text { Czujniki dymu i czadu posiada odpo- } \\
\text { wiednio } 18 \% \text { i } 17 \% \text { badanych }\end{array}$ \\
\hline $\begin{array}{l}\text { Every tenth respondent } \\
\text { indicates a failure of the gas } \\
\text { installation as the cause of } \\
\text { a fire / } \\
\text { Co dziesiąty respondent jako } \\
\text { przyczynę pożaru wskazuje } \\
\text { awarię instalacji gazowej }\end{array}$ & $\begin{array}{l}\text { Every second respondent declaring the } \\
\text { ability to recognize carbon monoxide } \\
(53 \% \text { ) indicates that it can be recognized } \\
\text { by smell (this is } 22 \% \text { of all the respon- } \\
\text { dents) / Co drugi respondent deklarujący } \\
\text { umiejętność rozpoznania czadu ( } 53 \% \text { ) } \\
\text { wskazuje, iż można go rozpoznać po za- } \\
\text { pachu (stanowi to } 22 \% \text { ogółu badanych) }\end{array}$ & $\begin{array}{l}28 \% \text { of the respondents declare } \\
\text { that in order to prevent a fire it is } \\
\text { enough to be careful (this approach } \\
\text { is more common in people with } \\
\text { lower education) / } 28 \% \text { respon- } \\
\text { dentów deklaruje, iż aby zapobiec } \\
\text { pożarowi wystarczy być uważnym } \\
\text { (podejście takie występuje częściej } \\
\text { u osób z niższym wykształceniem) }\end{array}$ & $\begin{array}{c}\text { A lower percentage of those with } \\
\text { detectors live in centrally located } \\
\text { voivodships / Niższy odsetek posiada- } \\
\text { jących czujniki zamieszkuje centralnie } \\
\text { położone województwa }\end{array}$ \\
\hline $\begin{array}{l}5 \% \text { of those asked indicated } \\
\text { the behavior of children as the } \\
\text { cause of the fires / } 5 \% \text { pyta- } \\
\text { nych jako przyczynę pożarów } \\
\text { wskazało zachowanie dzieci }\end{array}$ & $\begin{array}{c}\text { Every fifth respondent indicates the pos- } \\
\text { sibility of detecting carbon monoxide } \\
\text { using special detectors / } \\
\text { Co piąty pytany wskazuje możliwość } \\
\text { wykrycia czadu za pomocą specjalnych } \\
\text { czujników }\end{array}$ & $\begin{array}{l}\text { Every tenth respondent thinks that } \\
\text { one should have a fire extinguisher } \\
\text { (or other extinguisher device) at } \\
\text { home / Co dziesiąty pytany uważa, } \\
\text { że należałoby mieć w domu gaśni- } \\
\text { cę (lub inne urządzenie gaśnicze) }\end{array}$ & $\begin{array}{l}\text { The inhabitants of the following } \\
\text { voivodships have the greatest number } \\
\text { of detectors: dolnośląskie, opolskie, } \\
\text { małopolskie, zachodnio-pomorskie and } \\
\text { warmińsko-mazurskie / } \\
\text { Najwięcej czujników posiadają miesz- } \\
\text { kańcy województw: dolnośląskiego, } \\
\text { opolskiego, małopolskiego, zachodnio- } \\
\text { pomorskiego i warmińsko-mazurskiego }\end{array}$ \\
\hline
\end{tabular}


A person with a market qualification certificate "Installation and maintenance of alarm detectors: carbon monoxide, smoke, heat and gas" is prepared for independent installation and maintenance of fire safety monitoring devices and uses typical terminology related to the activities performed within the qualification. In his/her work, he/she applies health and safety rules and procedures relating to the performed tasks. During installation, instructing the user and providing maintenance of the detectors, he/she uses basic documents describing the operation and functioning of the installed devices. He/she can search, compare and evaluate the information needed to install and maintain alarm detectors in accordance with the art. In addition, he/ she solves common installation problems and gives instructions to the user on how to proceed in the event of an alarm triggered by the detector. In other words, he/she has the necessary minimum knowledge, competences and practical skills, guaranteeing an acceptable level of quality of installing the detector and providing maintenance services. Formal confirmation of previously proven skills constitutes a completely new standard in Poland, which may contribute to an increase in the number of households that will be equipped with these basic, but also strategic devices ensuring the safety of users and their property.

\section{Conclusions}

The key issue seems to be providing the assistance of qualified fitters and maintenance technicians of alarm detectors for dependent people with various dysfunctions, due to which they will not be able to purchase an appropriate detector on their own and then properly install it. These include people moving with the help of assistive equipment (crutches, walking sticks, walkers, prostheses, wheelchairs), with hearing and sight impairment, with manual and cognitive difficulties (e.g. after a stroke, with dementia), pregnant women, people who are physically weaker and have difficulty moving. The activity and independence of people with disabilities is difficult for various reasons. The development of new technologies and products in the field of compensation technologies allow for equal opportunities, but often the barrier is high prices of detectors or the inability to use them due to dysfunctions possessed by the users. Therefore, it is important not only to compensate for the effects of disability at an individual level, but above all to create conditions for building an environment that will be friendly and built on universal principles. This also applies to access to high-quality services in the field of fire protection. The new market qualification proposed by CNBOP-PIB called "Installation and maintenance of alarm detectors: carbon monoxide, smoke, heat and gas" can be used to educate staff that will be able to help out such a large group of citizens who, due to their dysfunctions, will never be able to independently purchase and install an alarm detector. At the same time, in an emergency, the same people will in most cases not be able to evacuate on their own, so more important is the need to provide them with information about a threat early enough to
Osoba posiadająca certyfikat kwalifikacji rynkowej „Montaż i konserwacja autonomicznych czujek: tlenku węgla, dymu, ciepła i gazu" jest przygotowana do samodzielnego montażu i konserwacji urządzeń monitorujących bezpieczeństwo pożarowe oraz posługuje się typowym nazewnictwem związanym z wykonywanymi działaniami w ramach kwalifikacji. W swojej pracy stosuje zasady i procedury BHP odnoszące się do wykonywanych zadań. W czasie montażu, instruowania użytkownika oraz w czasie konserwacji czujek korzysta z podstawowych dokumentów opisujących działanie i funkcjonowanie montowanych urządzeń. Potrafi wyszukiwać, porównywać i oceniać informacje potrzebne do montażu i konserwacji autonomicznych czujek zgodnie ze sztuką. Ponadto rozwiązuje typowe problemy pojawiające się podczas montażu oraz udziela instrukcji użytkownikowi o postępowaniu w sytuacji alarmu wywołanego przez czujkę. Jednym słowem, posiada niezbędne minimum wiedzy, kompetencji oraz umiejętności praktycznych, gwarantujące akceptowalny poziom jakości świadczonych usług montażu i konserwacji detektorów. Formalne potwierdzenie sprawdzonych uprzednio umiejętności stanowi zupełnie nowy standard w Polsce, który może przyczynić się do zwiększenia liczby gospodarstw domowych, które będą wyposażone w te podstawowe, ale jednocześnie strategiczne urządzenia zapewniające bezpieczeństwo użytkownikom oraz ich mieniu.

\section{Wnioski}

Kluczową sprawą wydaje się zapewnienie pomocy wykwalifikowanych monterów i konserwatorów autonomicznych czujek osobom niesamodzielnym, posiadającym różnego rodzaju dysfunkcje, z powodu których nie będą w stanie samodzielnie dokonać zakupu odpowiedniej czujki, a następnie prawidłowo jej zamontować. Należą do nich ludzie poruszający się przy pomocy sprzętu wspomagającego (kul, lasek, balkoników, protez, wózków inwalidzkich), z uszkodzonym narządem słuchu, wzroku, z trudnościami manualnymi i poznawczymi (na przykład po udarze, z chorobami otępiennymi), kobiety w ciąży, osoby słabsze fizycznie i mające trudności w poruszaniu się. Aktywność i samodzielność osób z niepełnosprawnościami jest z różnych powodów utrudniona. Rozwój nowych technologii oraz produktów z obszaru technologii kompensacyjnych pozwalają na wyrównywanie szans, ale często barierą pozostają wysokie ceny czujek lub brak możliwości ich zastosowania z powodu posiadanych przez użytkowników dysfunkcji. Dlatego ważne jest, aby nie tylko kompensować skutki niepełnosprawności na poziomie indywidualnym, ale przede wszystkim stwarzać warunki do budowy otoczenia, które będzie przyjazne i zbudowane na zasadach uniwersalnych. Dotyczy to również dostępu do odpowiednich jakościowo usług z obszaru ochrony przeciwpożarowej. Zaproponowana przez CNBOP-PIB nowa kwalifikacja rynkowa pt. "Montaż i konserwacja autonomicznych czujek: tlenku węgla, dymu, ciepła i gazu" może posłużyć wykształceniu kadr, które będą mogły wyręczyć tak liczną grupę obywateli, którzy z powodu posiadanych dysfunkcji, nigdy nie będą $\mathrm{w}$ stanie samodzielnie dokonać zakupu oraz montażu autonomicznej czujki. Jednocześnie w sytuacji zagrożenia, te same osoby nie będą w większości przypadków zdolne do samodzielnej ewakuacji, więc tym 
enable the appropriate services to be called. For this reason, equipping the residential buildings of people from this group with the detectors in question seems to be a key issue in order to maintain an appropriate level of safety.

The ability to confirm qualifications regarding the design, installation and maintenance of fire protection at CNBOPPIB is the first important step towards a comprehensive solution offered by the Integrated Qualification System in fire protection. Details in this regard will be published successively on CNBOP-PIB website at https://www.cnbop.pl/pl/uslugi/ jednostka-certyfikujaca-uslugi/certyfikacja-personelu.

ZSK, having its formal foundations in the rank of statutory provisions and executive acts, is a well-described system of formal organization and classification of competences in comparable qualifications frameworks in Poland and the EU. However, the system is flexible and takes into account the principle of lifelong learning in different ways. It is an open system - in case of market qualifications, their confirmation takes place on the basis of validation, but it does not matter how the knowledge was obtained by the person who participated in it. Thus, education itself, participation in training, and practical acquisition of knowledge and skills are possible. The idea and offer of ZSK in fire protection in Poland, presented in a synthetic way, against the background of systemic solutions adopted in developed countries in Europe, indicates the need to introduce similar solutions in Poland, thus offering the society (including particularly vulnerable people) services at the highest possible quality level. This is essential for the effectiveness of the technological and organizational solutions offered in the field of fire protection in the 21 st century.

Based on the analysis of the conducted research, a significant lack of adequate public awareness of fire hazards, their identification and the possibility of preventing them was discovered. Regardless of the activities related to the introduction of market qualifications, activities aimed at increasing public awareness of fire safety are identified as highly justified and extremely important. Informing the public about the dangers and methods of preventing and dealing with them, as well as the impact of equipping households with appropriate detectors and their correct installation and operation on safety, is an extremely important aspect of improving fire safety of residential buildings.

\section{Literature / Literatura}

[1] Norma PN-EN 14604:2006 Autonomiczne czujki dymu.

[2] Norma PN-EN 54-3+A1:2019-06 Systemy sygnalizacji pożarowej - Część 3: Pożarowe urządzenia alarmowe - Sygnalizatory akustyczne.

[3] PKN-CEN/TS 54-14:2020-09 Systemy sygnalizacji pożarowej - Część 14: Wytyczne planowania, projektowania, instalowania, odbioru, eksploatacji i konserwacji. bardziej większego znaczenia nabiera konieczność odpowiednio wczesnego przekazania im informacji o zagrożeniu tak, aby umożliwić wezwanie odpowiednich służb. $Z$ tego powodu wyposażenie obiektów mieszkalnych osób z tej grupy w omawiane czujniki, wydaje się kluczową sprawą w celu zachowania odpowiedniego poziomu bezpieczeństwa.

Możliwość potwierdzenia kwalifikacji dotyczących projektowania, montażu i konserwacji zabezpieczeń przeciwpożarowych w CNBOP-PIB to pierwszy ważny krok w stronę kompleksowego rozwiązania, jakie oferuje Zintegrowany System Kwalifikacji w ochronie przeciwpożarowej. Szczegóły w tym zakresie będą ogłaszane sukcesywnie na stronie internetowej CNBOP-PIB https://www.cnbop.pl/pl/uslugi/jednostka-certyfikujaca-uslugi/ certyfikacja-personelu.

ZSK, posiadając swoje podstawy formalne $w$ randze przepisów ustawowych i aktów wykonawczych, jest dobrze opisanym systemem formalnego uporządkowania i klasyfikacji kompetencji w porównywalnych ramach kwalifikacji w Polsce i UE. Jednakże system ten jest elastyczny i uwzględnia zasadę nauki przez całe życie w różny sposób. Jest on systemem otwartym - w przypadku kwalifikacji rynkowych ich potwierdzenie odbywa się na zasadzie walidacji, przy czym nie ma znaczenia, w jaki sposób wiedza ta została pozyskana przez osobę, która się jej poddaje. Możliwa jest zatem sama edukacja, udział w szkoleniach, praktyczne zdobywanie wiedzy i umiejętności. Przedstawiona w sposób syntetyczny idea i oferta ZSK w ochronie przeciwpożarowej w Polsce na tle systemowych rozwiązań przyjętych w państwach rozwiniętych Europy, wskazuje potrzebę wprowadzenia podobnych rozwiązań w Polsce, oferując tym samym społeczeństwu (w tym osobom szczególnie zagrożonym) usługi na możliwie najwyższym poziomie jakościowym. Ma to kluczowe znaczenie dla skuteczności oferowanych rozwiązań technologicznych i organizacyjnych w ochronie przeciwpożarowej w XXI wieku.

Na podstawie analizy przeprowadzonych badań stwierdzono znaczący brak odpowiedniej świadomości społecznej na temat zagrożeń pożarowych, ich identyfikacji i możliwości zapobiegania im. Niezależnie od działań związanych z wprowadzeniem kwalifikacji rynkowych, jako wysoce zasadne i niezwykle istotne identyfikuje się działania zmierzające do podniesienia świadomości społecznej w zakresie bezpieczeństwa pożarowego. Informowanie społeczeństwa zarówno o zagrożeniach i sposobach zapobiegania i postępowania w razie ich wystąpienia, jak również o wpływie wyposażenia gospodarstw domowych w odpowiednie czujki oraz o ich prawidłowym montażu i eksploatacji na bezpieczeństwo, stanowi niezwykle istotny aspekt poprawy bezpieczeństwa pożarowego obiektów mieszkalnych.

[4] Norma PN-EN 50291-1:2018 Wykrywacze gazu - Urządzenia elektryczne do wykrywania tlenku węgla w pomieszczeniach domowych - Część 1: Metody badań i wymagania eksploatacyjne.

[5] Ustawa z dnia 24 sierpnia 1991 r. o ochronie przeciwpożarowej (Dz. U. z 2019 r. poz. 1372; zm.: Dz. U. z 2019 r. poz. 1518).

[6] Rozporządzenie Parlamentu Europejskiego i Rady (UE) nr 
305/2011 z dnia 9 marca 2011 r. ustanawiającego zharmonizowane warunki wprowadzania do obrotu wyrobów budowlanych i uchylające dyrektywę Rady 89/106/EWG (Dz. U. L 88/5 z 4.4.2011).

[7] Ustawa z dnia 16 kwietnia 2004 r. o wyrobach budowlanych (Dz. U. nr 92 poz. 881 z późn. zm.).

[8] Rozporządzenie Ministra Infrastruktury i Budownictwa z dnia 17 listopada 2016 r. w sprawie sposobu deklarowania właściwości użytkowych wyrobów budowlanych oraz sposobu znakowania ich znakiem budowlanym (Dz. U. z 2016 r. poz. 1966 z późn. zm.).

[9] Czujniki dymu są obowiązkowe - kampania Ei Electronics, https://www.eielectronics.de/rauchmelder-sind-pflicht [dostęp: 8.06.2021].

[10] Obwieszczenie Ministra Spraw Wewnętrznych i Administracji z dnia 7 maja 2019 r. w sprawie włączenia kwalifikacji rynkowych dotyczących projektowania, montażu i konserwacji zabezpieczeń przeciwpożarowych oraz montażu i konserwacji autonomicznych czujek: tlenku węgla, dymu, ciepła i gazu do Zintegrowanego Systemu Kwalifikacji (Monitor Polski z dnia 21 maja 2019 r. poz. 446).

[11] Decyzja Ministra Spraw Wewnętrznych i Administracji z dnia 9 lipca 2019 r. w sprawie nadania Centrum Naukowo-Badawczemu Ochrony Przeciwpożarowej im. Józefa Tuliszkowskiego - Państwowemu Instytutowi Badawczemu uprawnienia do certyfikowania kwalifikacji rynkowych (Monitor Polski z dnia 21 maja 2019 r. poz. 446).

[12] Ipsos, Badania dot. zagrożenia pożarowego oraz zatruć tlenkiem węgla i dymem, https://slideplayer.pl/ slide/11730879/ [dostęp: 8.06.2021].

[13] Garlińska U., Iwańska M., Śliwiński R., Najnowsze prawodawstwo krajów europejskich i jego porównanie ze stanem obowiązującym w Polsce w zakresie autonomicznych czujek dymu, „Ochrona Mienia i Informacji” 2016, 4, 42-45.

[14] Garlińska U., Iwańska M., Śliwiński R., Autonomiczna czujka dymu - opis działania i funkcjonalność wyrobu, „Ochrona Mienia i Informacji" 2016, 5, 44-46.

[15] Ustawa z dnia 22 grudnia 2015 r. o Zintegrowanym Systemie Kwalifikacji (Dz. U. z 2018 poz. 2153 z późn. zm.).

[16] Zboina J., Gancarczyk P. (red.), Certyfikacja usług w ochronie przeciwpożarowej w ujęciu praktycznym i teoretycznym, Wydawnictwo CNBOP-PIB, Józefów 2016, https://doi. org/10/17381/2016.1

[17] Sławiński S., Mała encyklopedia Zintegrowanego Systemu Kwalifikacji, Wydawnictwo Instytutu Badań Edukacyjnych, Warszawa 2018.

[18] Sławiński S., Stownik Zintegrowanego Systemu Kwalifikacji, Wydawnictwo Instytutu Badań Edukacyjnych, Warszawa 2018.

[19] Sławiński S., Królik K., Stęchły W., Włączanie kwalifikacji do Zintegrowanego Systemu Kwalifikacji, Wydawnictwo Instytutu Badań Edukacyjnych, Warszawa 2018.

[20] Gmaj I., Grzeszczak J., Leyk A. i in., Walidacja - nowe możliwości zdobywania kwalifikacji, Wydawnictwo Instytutu Badań Edukacyjnych, Warszawa 2018.

[21] The Smoke and Carbon Monoxide Alarm (England) Regulations 2015, https://www.legislation.gov.uk/ uksi/2015/1693/contents/made [dostęp: 8.06.2021].

[22] Median annual earnings for full-time employees in the United Kingdom from 1999 to 2020 (in GBP), https://www. statista.com/statistics/1002964/average-full-time-annual-earnings-in-the-uk [dostęp: 8.06.2021].
PAWE $\leftarrow$ FLOREK, BE - a graduate of the Faculty of Law at the SWPS University of Social Sciences and Humanities in Warsaw, where he graduated from the Faculty of Internal Security. Specialist in the Support and Audit Department at Centrum Naukowo-Badawcze Ochrony Przeciwpożarowej - Państwowy Instytut Badawczy in Józefów. Fire protection inspector, member of a team of authors of 7 new qualifications in the field of design, installation and maintenance of fire protection at CNBOP-PIB included in ZSK, as well as the originator of the qualification for the installation and maintenance of alarm detectors.

URSZULA GARLIŃSKA, M.SC. ENG. - a graduate of the Faculty of Civil Safety Engineering and the Faculty of Fire Safety Engineering of the Main School of Fire Service in Warsaw and post-graduate student of the Warsaw University of Technology and the University of Information Technology and Management in Rzeszów. Research and technical employee of Fire Alarm Systems and Fire Automation Laboratory in Centrum Naukowo-Badawcze Ochrony Przeciwpożarowej - Państwowy Instytut Badawczy (CNBOP-PIB) in Józefów.
LIC. PAWE FLOREK - absolwent Wydziału Prawa SWPS Uniwersytetu Humanistycznospołecznego w Warszawie, gdzie ukończył studia na kierunku Bezpieczeństwo Wewnętrzne. Specjalista w Dziale Wsparcia i Audytów w Centrum Naukowo-Badawczym Ochrony Przeciwpożarowej - Państwowym Instytucie Badawczym w Józefowie. Inspektor ochrony przeciwpożarowej, członek zespołu autorów 7 nowych kwalifikacji z zakresu projektowania, montażu i konserwacji zabezpieczeń przeciwpożarowych w CNBOP-PIB włączonych do ZSK, a także pomysłodawca kwalifıkacji dotyczącej montażu i konserwacji autonomicznych czujek.

MGR INŻ. URSZULA GARLIŃSKA - absolwentka Wydziału Inżynierii Bezpieczeństwa Cywilnego i Wydziału Inżynierii Bezpieczeństwa Pożarowego Szkoły Głównej Służby Pożarniczej w Warszawie oraz studiów podyplomowych na Politechnice Warszawskiej i Wyższej Szkoły Informatyki i Zarządzania w Rzeszowie. Pracownik badawczo-techniczny w Zespole Laboratoriów Sygnalizacji Alarmu Pożaru i Automatyki Pożarniczej w Centrum Naukowo-Badawczym Ochrony Przeciwpożarowej - Państwowym Instytucie Badawczym w Józefowie. 
MARTA IWAŃSKA, M.SC. - a graduate of Collegium Civitas in Warsaw at the Faculty of Sociology, with a major in management of non-governmental organizations. For over eight years she has been working in CNBOP-PIB Certification Department as a specialist in quality management systems. She is a co-author of a number of publications related to fire protection.

ROBERT ŚLIWIŃSKI, M.SC. ENG. - a graduate of the Faculty of Civil Safety Engineering at the Main School of Fire Service in Warsaw and the SGH Warsaw School of Economics. From the beginning of his professional career, he was associated with Centrum Naukowo-Badawcze Ochrony Przeciwpożarowej - Państwowy Instytut Badawczy (CNBOP-PIB) in Józefów. As a specialist of the Certification Department, he was the coordinator of a substantive area regarding devices included in the fire alarm systems. From 2019, deputy manager of CNBOP-PIB Technical Assessment Department.
MGR MARTA IWAŃSKA - absolwentka Collegium Civitas w Warszawie na wydziale socjologii, kierunek zarządzanie organizacjami pozarządowymi. Od ponad ośmiu lat pracownik Jednostki Certyfikującej w Centrum Naukowo-Badawczym Ochrony Przeciwpożarowej - Państwowym Instytucie Badawczym w Józefowie jako specjalista ds. systemów zarządzania jakością. Współautorka szeregu publikacji związanych z ochroną przeciwpożarową.

MGR INŻ. ROBERT ŚLIWIŃSKI - absolwent Wydziału Inżynierii Bezpieczeństwa Cywilnego Szkoły Głównej Służby Pożarniczej w Warszawie oraz Szkoły Głównej Handlowej. Od początku kariery zawodowej związany z Centrum Naukowo-Badawczym Ochrony Przeciwpożarowej - Państwowym Instytutem Badawczym w Józefowie. Jako specjalista Jednostki Certyfikującej pełnił rolę koordynatora obszaru merytorycznego dot. urządzeń wchodzących w skład systemów sygnalizacji pożarowej. Od 2019 roku Zastępca Kierownika Zakładu Ocen Technicznych CNBOP-PIB. 